\title{
JARLSBERG
}

\section{Containment Data Report}

\author{
Billy Hudson \\ Ted Stubbs \\ Ray Heinle
}

December 1994

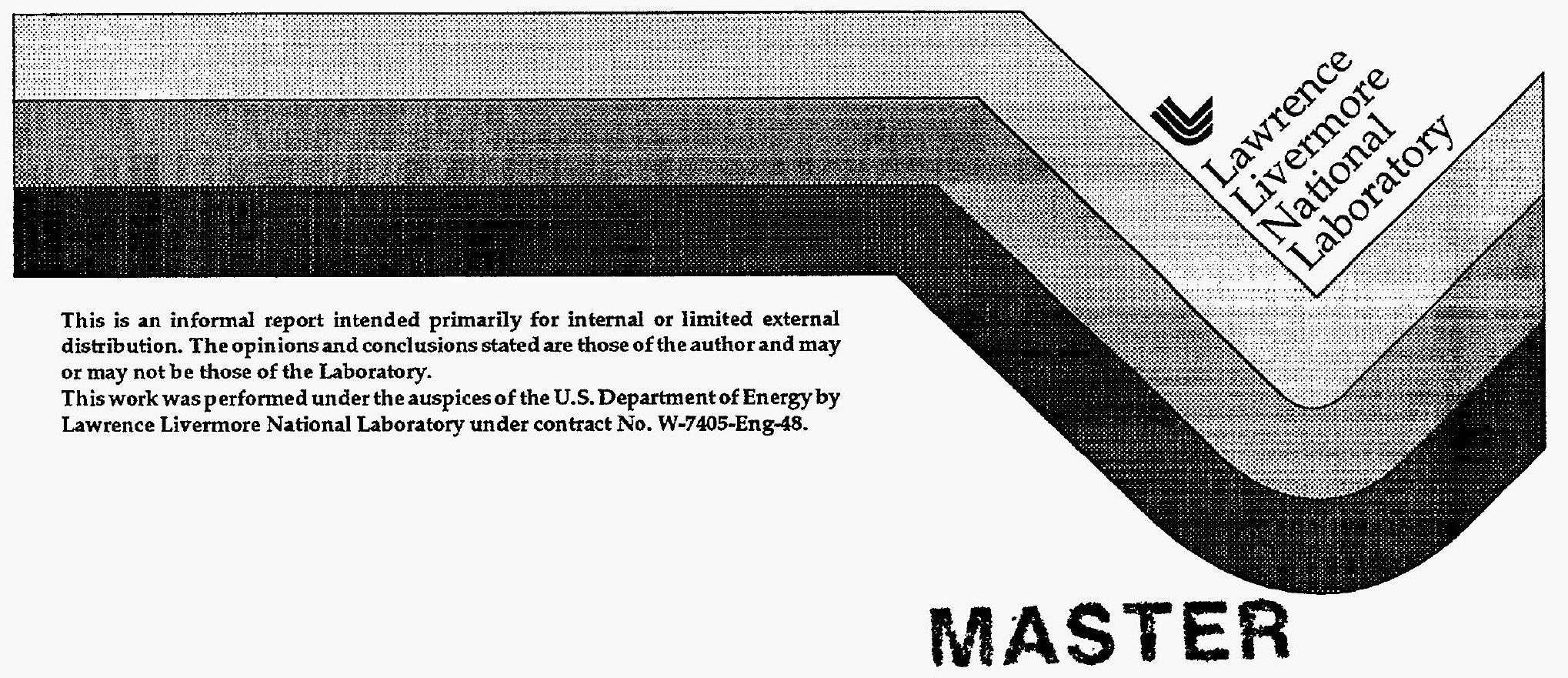

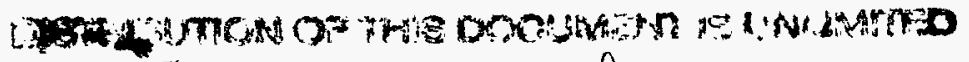


This document was prepared as an account of work sponsored by an agency of the United States Government. Neither the United States Government nor the University of California nor any of their employees, makes any warranty, express or implied, or assumes any legal liability or responsibility for the accuracy, completeness, or usefulness of any information, apparatus, product, or process disclosed, or represents that its use would not infringe privately owned rights. Reference herein to any specific commercial product, process, or service by trade name, trademark, manufacturer, or otherwise, does not necessarily constitute or imply its endorsement, recommendation, or favoring by the United States Government or the University of California. The views and opinions of authors expressed herein do not necessarily state or reflect those of the United States Government or the University of California, and shall not be used for advertising or product endorsement purposes.

This report has been reproduced directly from the best available copy.

Available to DOE and DOE contractors from the Office of Scientific and Technical Information

P.O. Box 62, Oak Ridge, TN 37831

Prices available from (615) 576-8401, FTS 626-8401

Available to the public from the

National Technical Information Service

U.S. Department of Commerce

5285 Port Royal Rd.

Springfield, VA 22161 


\section{DISCLAIMER}

Portions of this document may be illegible in electronic image products. Images are produced from the best available original document. 


\begin{tabular}{lll} 
Classification Guide & Topic Number & \multicolumn{1}{c}{ Subiect } \\
\cline { 2 - 3 } COK-88-024 & 1.5 .6 & Event announcernent \\
NV-89-18 & & Event announcement \\
TCG-WT-1 & 1113 & Contractor identification \\
TCG-WT-1 & 1121 & Personnel identification \\
TCG-WT-1 & 1210 & Geology \\
TVG-WT-1 & 1260 & Crater (map) \\
TCG-WT-1 & 1413 & Statement concerning venting \\
TCG-WT-1 & 1452 & Event announcement \\
TCG-WT-1 & 1831 & Depth of burial \\
TCG-WT-1 & 1843 & Stemming material, amount,etc \\
TCG-WT-1 & 1925 & Diagnostic canister dimensions \\
TCG-WT-1 & 3542.3 & Ground motion \\
TCG-WT-1 & 4810 & Radiation measurement \\
TCG-WT-1 & 4820 & Acceleration, pressure, \\
& & temperature measurement
\end{tabular}


ARLSBERG Instrumentation Summany

\begin{tabular}{|c|c|c|c|}
\hline Instrumentation & Fielded & $\begin{array}{c}\text { Data } \\
\text { Return }\end{array}$ & $\begin{array}{l}\text { Present in } \\
\text { this Report }\end{array}$ \\
\hline Plug Emplacement $(a)$ & yes & yes & yes \\
\hline Radiation & yes & yes & yes \\
\hline \multicolumn{4}{|l|}{ Pressure } \\
\hline Stemming & yes & yes & yes \\
\hline Challenge & no & - & - \\
\hline Cavity & no & - & - \\
\hline Atmospheric & no & - & - \\
\hline \multicolumn{4}{|l|}{ Motion } \\
\hline Free field & yes & yes & yes \\
\hline Surface & yes & yes & yes \\
\hline Plug & yes & yes & yes \\
\hline Stemming & no & - & - \\
\hline Surface casing & yes (a) & yes & yes \\
\hline Emplacement pipe & yes $(a)$ & yes & yes \\
\hline Recording trailer & no & - & - \\
\hline Hudrovield & no & - & - \\
\hline Collapse (b) & yes & yes & yes \\
\hline Stress & yes & yes & yes \\
\hline Strain $(c)$ & yes & yes & yes \\
\hline Other Measurements (d) & yes & no & - \\
\hline
\end{tabular}

(a) Relative displacement between stemming, emplacement pipe, and casing.

(b) CLIPER in emplacement hole.

(c) Emplacement pipe, emplacement plug, and stemming.

(d) D-cable indicator for plug emplacement.

\section{Event Personnel}

\section{Containment Physics}
B. Hudson
C. Sisemore
V. Wheeler
LLNL
LLNL
J. Kalinowski
LLNL
EG\&G/AVO
T. Stubbs
EG\&G/AVO

Instrumentation

$\begin{array}{ll}\text { C. Cordill } & \text { LLNL } \\ \text { T. Valk } & \text { LLNL } \\ \text { T. Brown } & \text { EG\&G/AVO } \\ \text { W. Webb } & \text { EG\&G/NVO } \\ \text { P. Tanner } & \text { EG\&G/NVO }\end{array}$




\section{Table of Contents}

1. Event Description

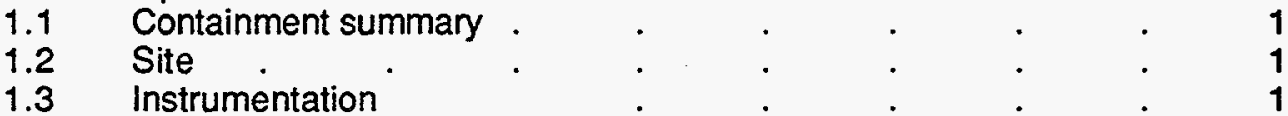

2. Emplacement

2.1 Pipe strain . . . . 10

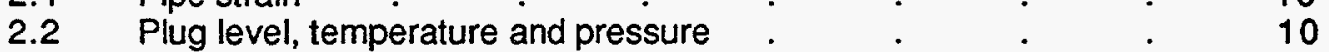

3. Stemming performance

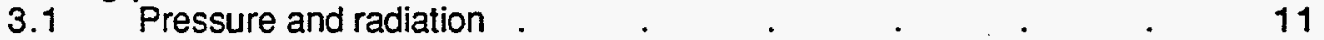

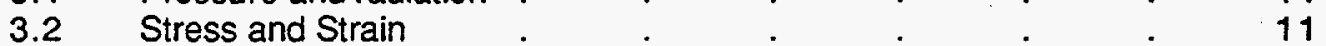

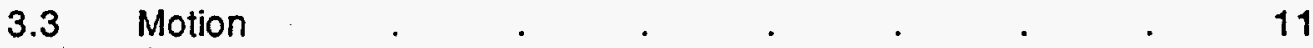

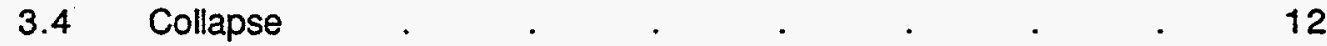

4. Surface Motion . $\quad . \quad$. $\quad$. $\quad$. $\quad$. $\quad . \quad . \quad 21$

5. Satellite hole (free-field) measurements

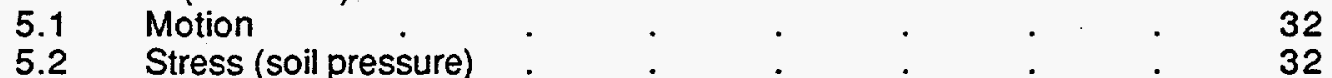

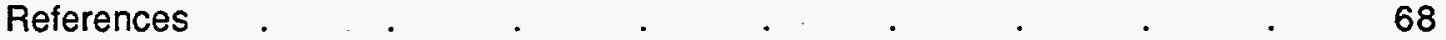




\section{Event Description}

\subsection{Containment summary}

JARLSBERG was detonated on August 27, 1983 at 07:00 PDT. All phenomena appeared normal with chimney collapse reaching the ground surface about 15 minutes later. The average radius of the resulting crater was $41.4 \mathrm{~m}$ and the depth at surface-ground-zero (SGZ) was $7.0 \mathrm{~m}$.

No radiation was detected above ground and the containment was satisfactory.

\subsection{Site}

JARLSBERG was located in hole U10ca of the Nevada Test Site as shown in Figure 1.1. A depth of burst of $200 \mathrm{~m}$ placed the detonation in the layered tuffs about $100 \mathrm{~m}$ above the Paleozoic contact and nearly $300 \mathrm{~m}$ above the static water level. Geologic cross sections through this hole and plan maps of the local region are shown in Figures 1.2 and $1.3^{(1)}$. The stemming plan of the $2.24 \mathrm{~m}$ diameter hole is shown in Figure 1.4.

\subsection{Instrumentation}

Containment instrumentation for the emplacement hole is shown in Figure 1.5. Further details of the instrumentation installation is given in Reference 2.

The satellite hole, Ue10aa, was instrumented for both stress and motion as shown in Figure 1.6. The gauge stations were emplaced on a fiber-glass pipe and the $0.31 \mathrm{~m}$ diameter hole grouted to within $36 \mathrm{~m}$ of the surface with the remainder of the hole stemmed with twopart-epoxy (TPE).

As indicated in Figure 1.7, an array of six vertical motion stations were placed near the ground surface at a depth of $0.61 \mathrm{~m}$. 
A pre-shot lightning strike on the grounding system destroyed several transducers and possibly damaged others. Those transducer channels which appeared to have been damaged due to lightning or other phenomena are:

Emplacement hole: All strain gauge channels except 82 and all pressure and radiation channels.

Satellite hole: Stations 42 and 43, were dead pre-shot; channels 41uv, 47at, 48uv, and 49ut were damaged by shock. Data from all stress (soil pressure) channels except $54 \mathrm{~s}$ appeared invalid.

Surface array: Channels 63av, 64uv, 65uv, and 66uv, were all damaged by EMP. 


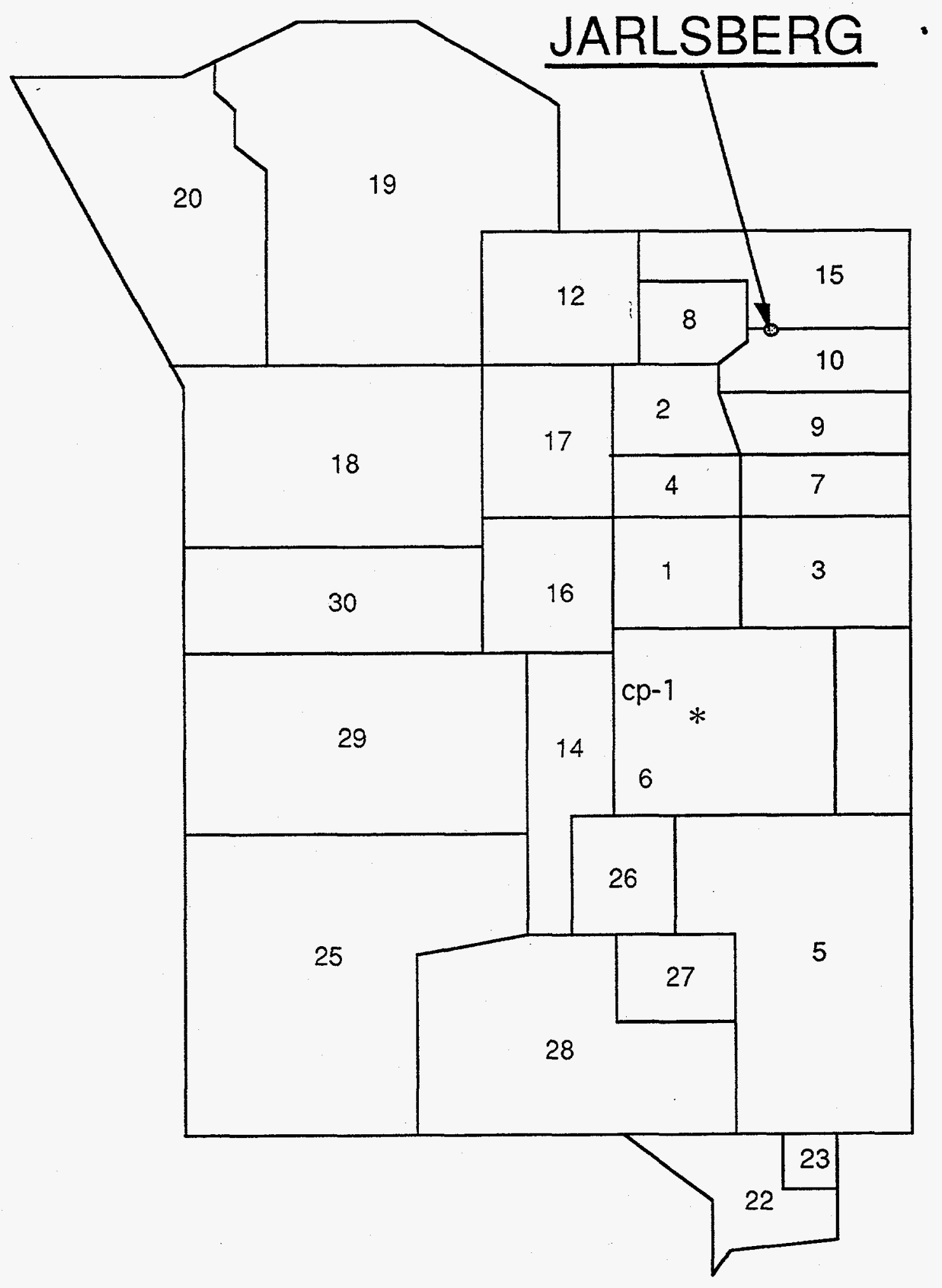

Figure 1.1 Map of the Nevada Test Site indicating the location of hole U10ca. 


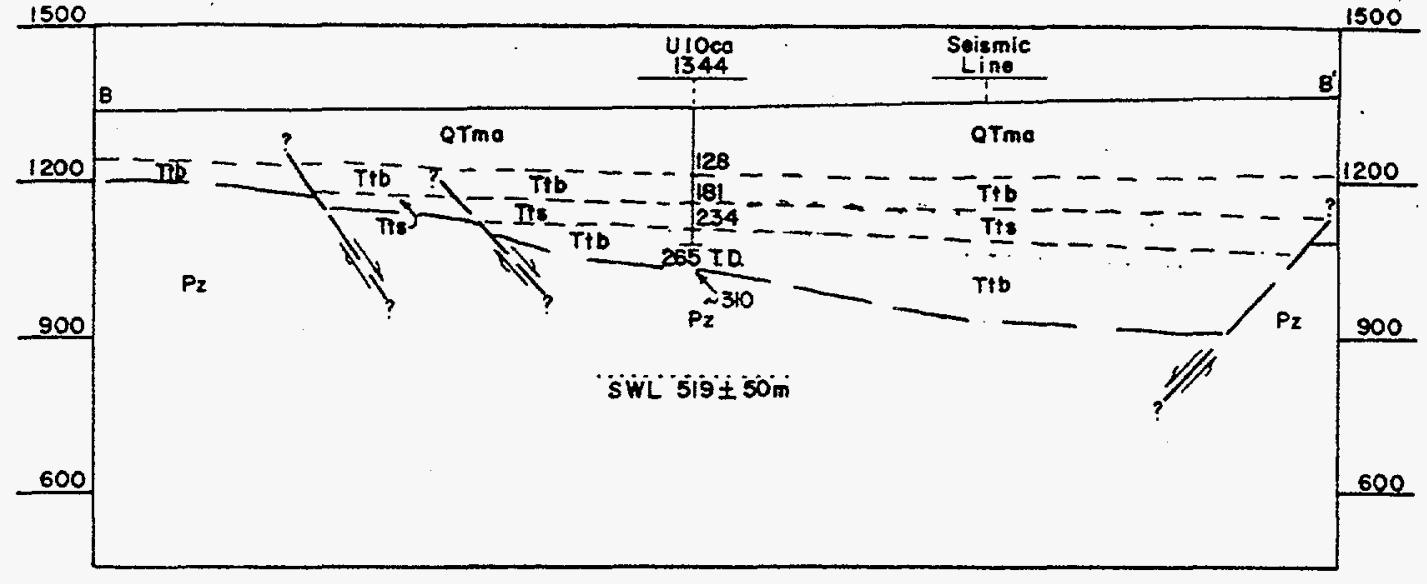

\section{LEGEND}

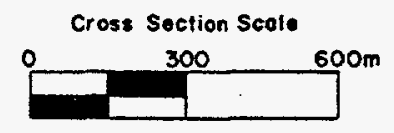

\section{Mixed olluvium}

Bosol tuffaceous olluvium

Painfbeush Tuft

Grouse Conyon Airfoll

Tunnel Beds

Tub Springs Member

Paleozoic or Precombrien Sedimentary Rocks

Inferred fault based on seismic and for grovity date.

\section{GEOLOGIC CROSS SECTION B-B' Of UIOCO}

Bend in section

Paleozoic or Pracambrion log

Static woter level

Seismic reflection line

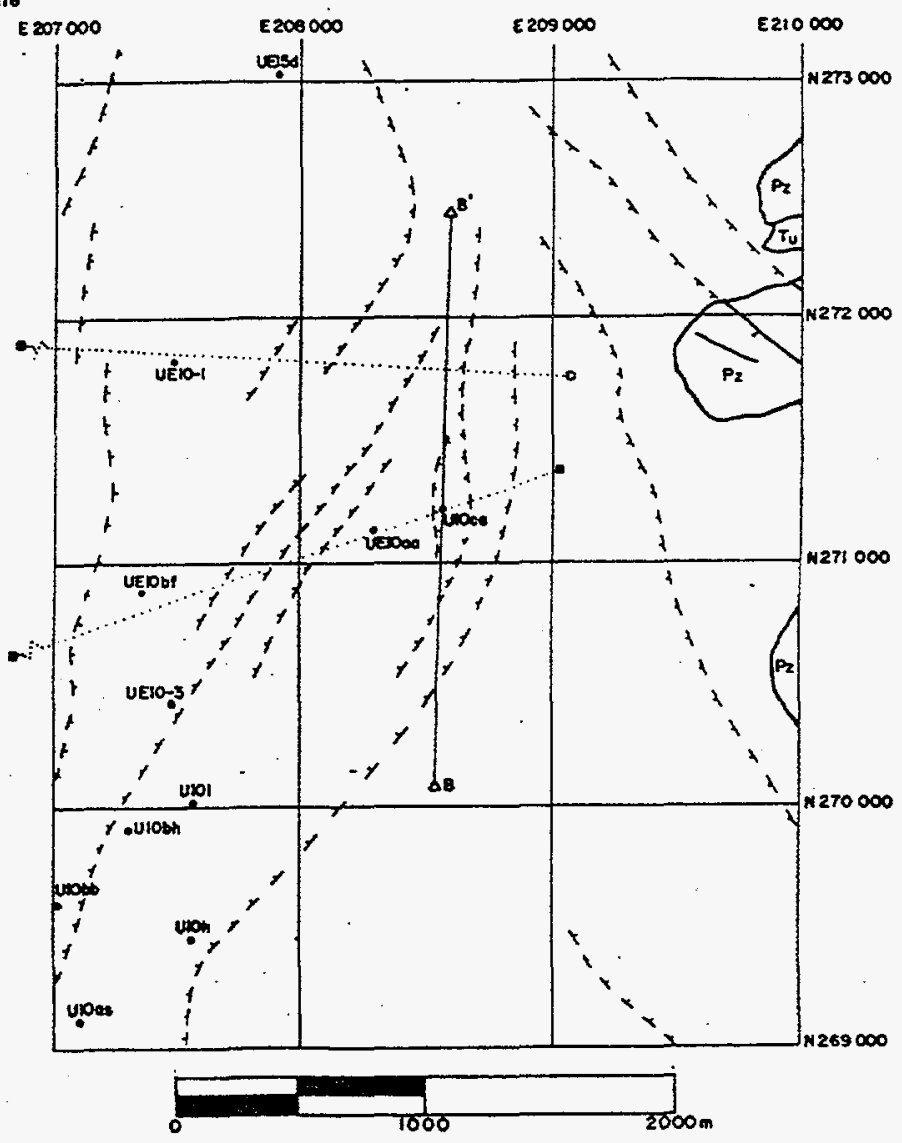

Figure 1.2 Plan view of the region near Hole U10ca with a North-South geologic cross section through the hole. 


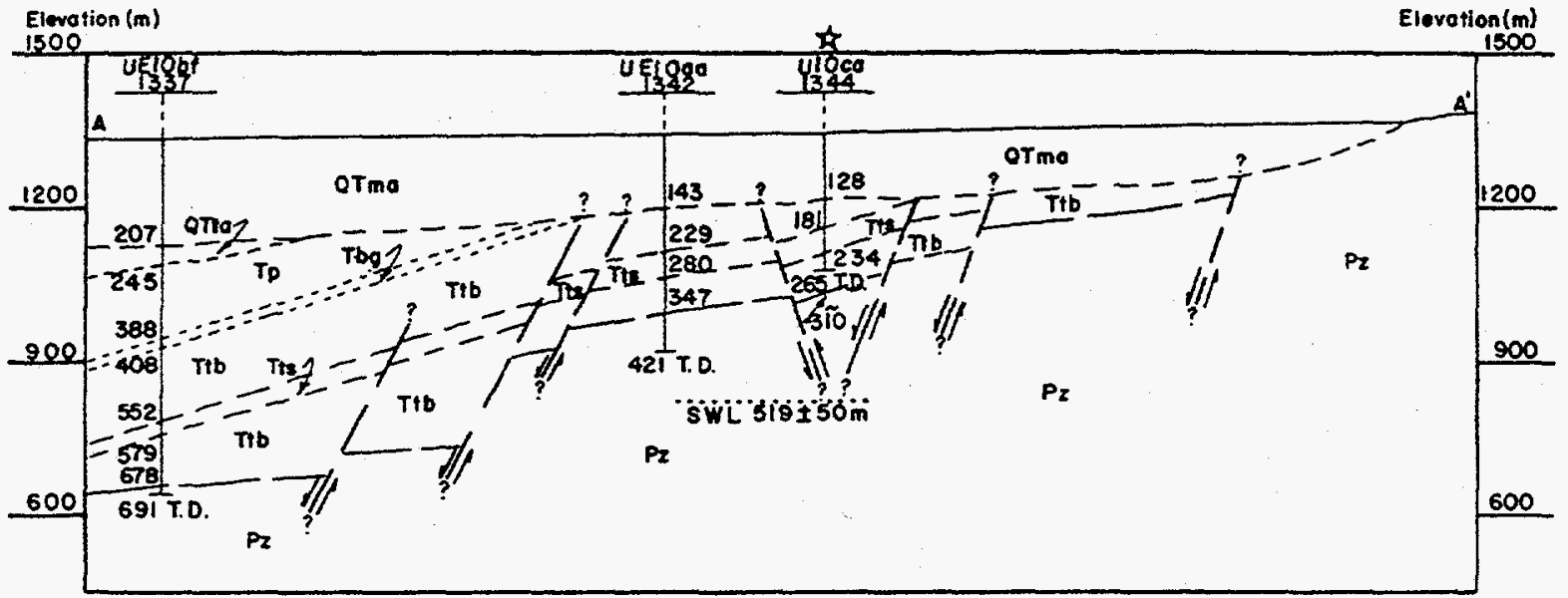

\section{LEGEN D}

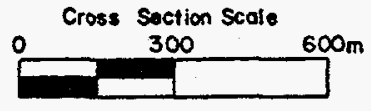

QTmo Mixed alluvium

QTio Bosal tutfocoous alluvium

Tp Pointbrush Tutf

Too Grouse Conyon Airfall

Ttb Tunnel Beds

Tub Springs Member

Poleozoic or Precambrion Sedimentory Rocks

Inferred foull bosed on seismic ond/or grovity data.

Bend in section

Poleozoic or Procambrion lag

Stalic water level

Seismic reflection line

GEOLOGIC CROSS SECTION A-A' of UIOCO

gut JLW 4-8-83

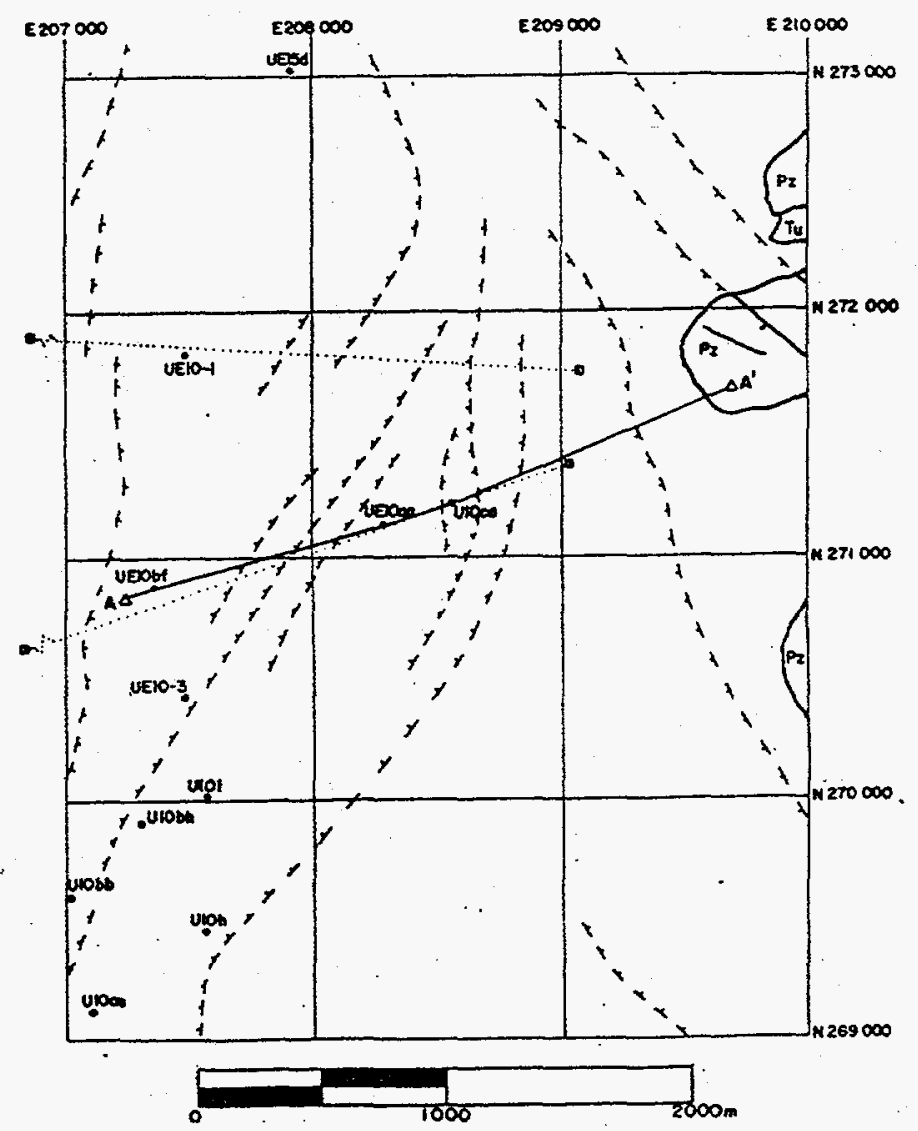

Figure 1.3 Plan view of the region near Hole U10ca with an East-West geologic cross section through the hole. 


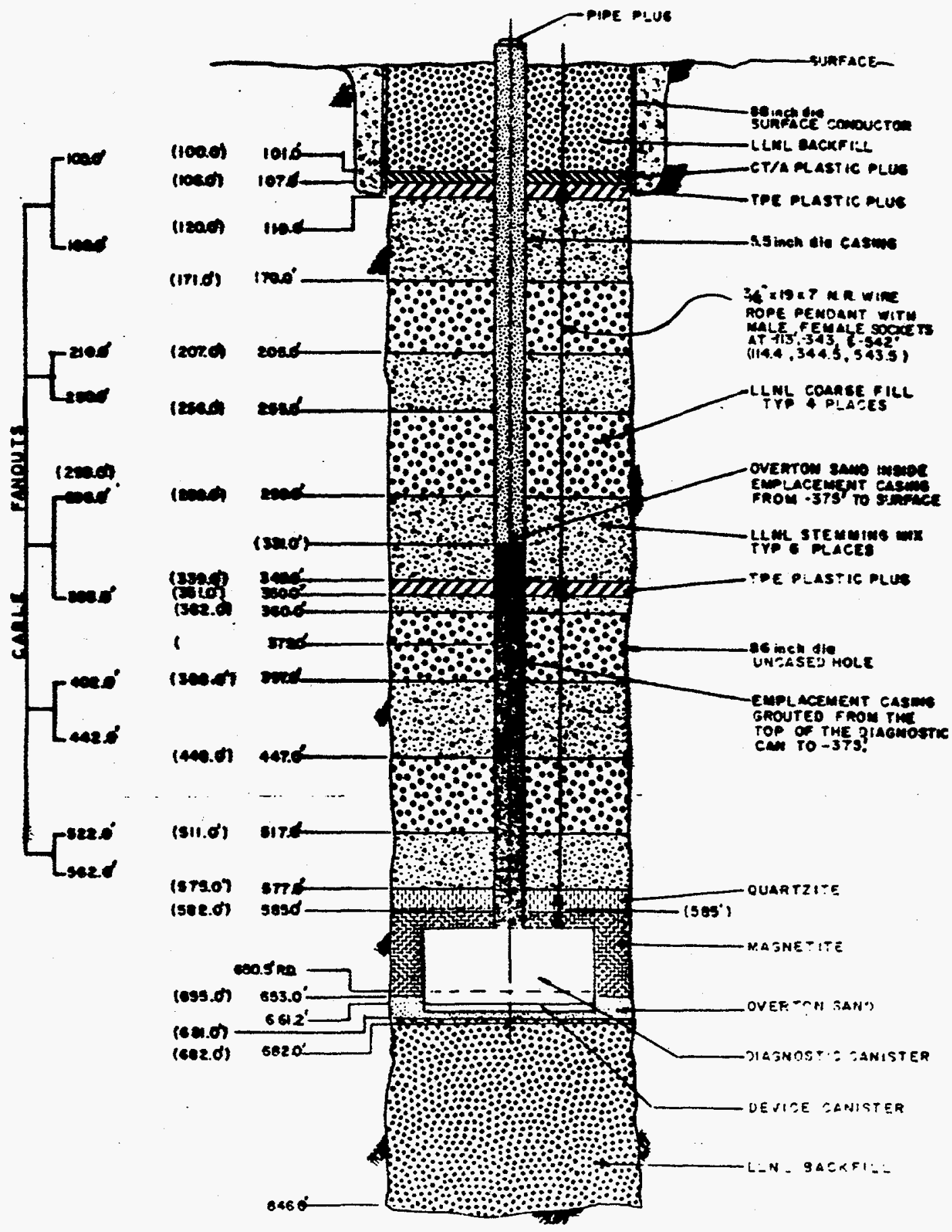

HOL WES HARVER IMC.

Figure 1.4 As-built stemming plan for hole U10ca. 


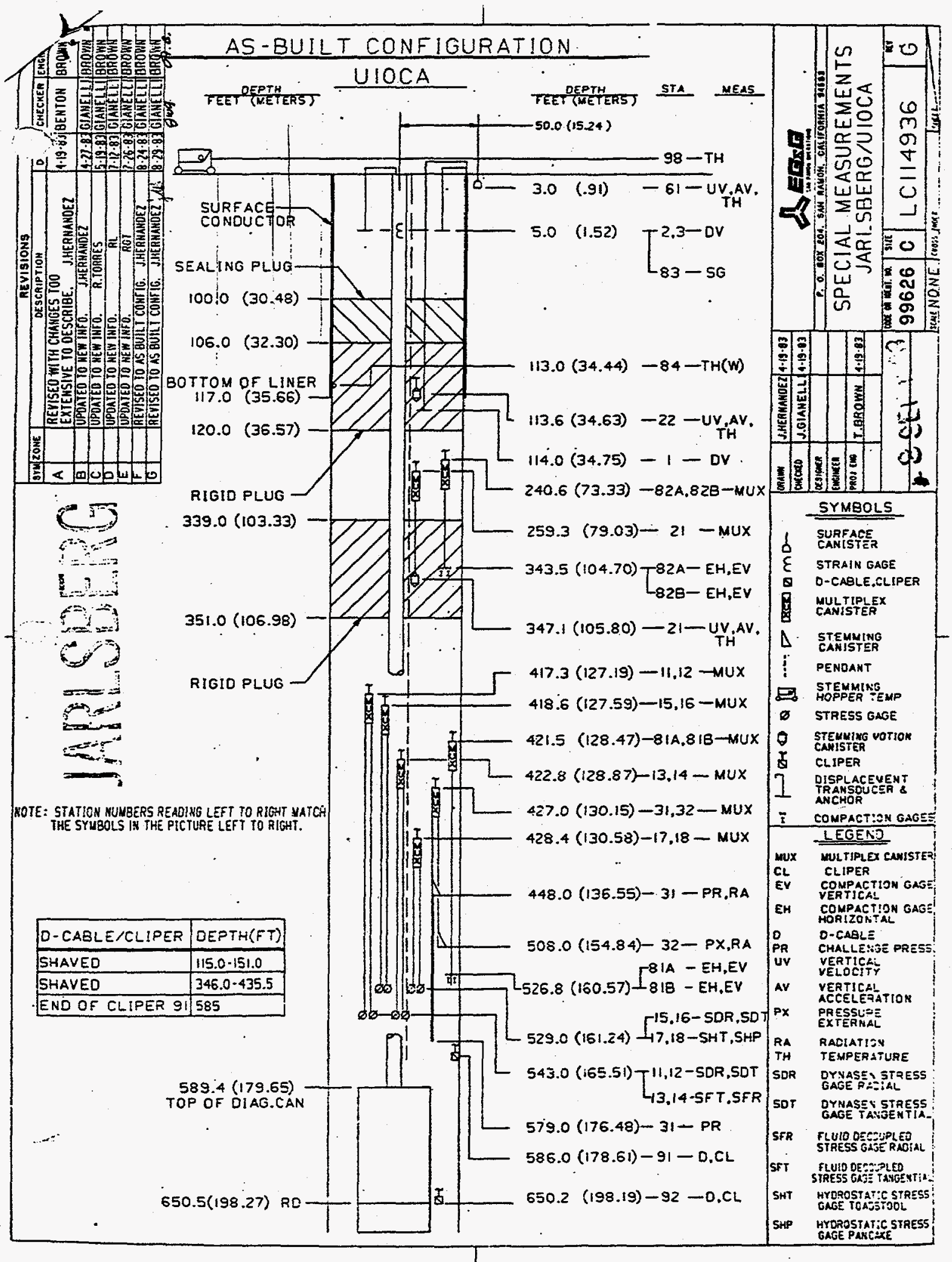

Figure 1.5 As-built instrumentation plan for the JARLSBERG event emplacement hole, U10ca. 


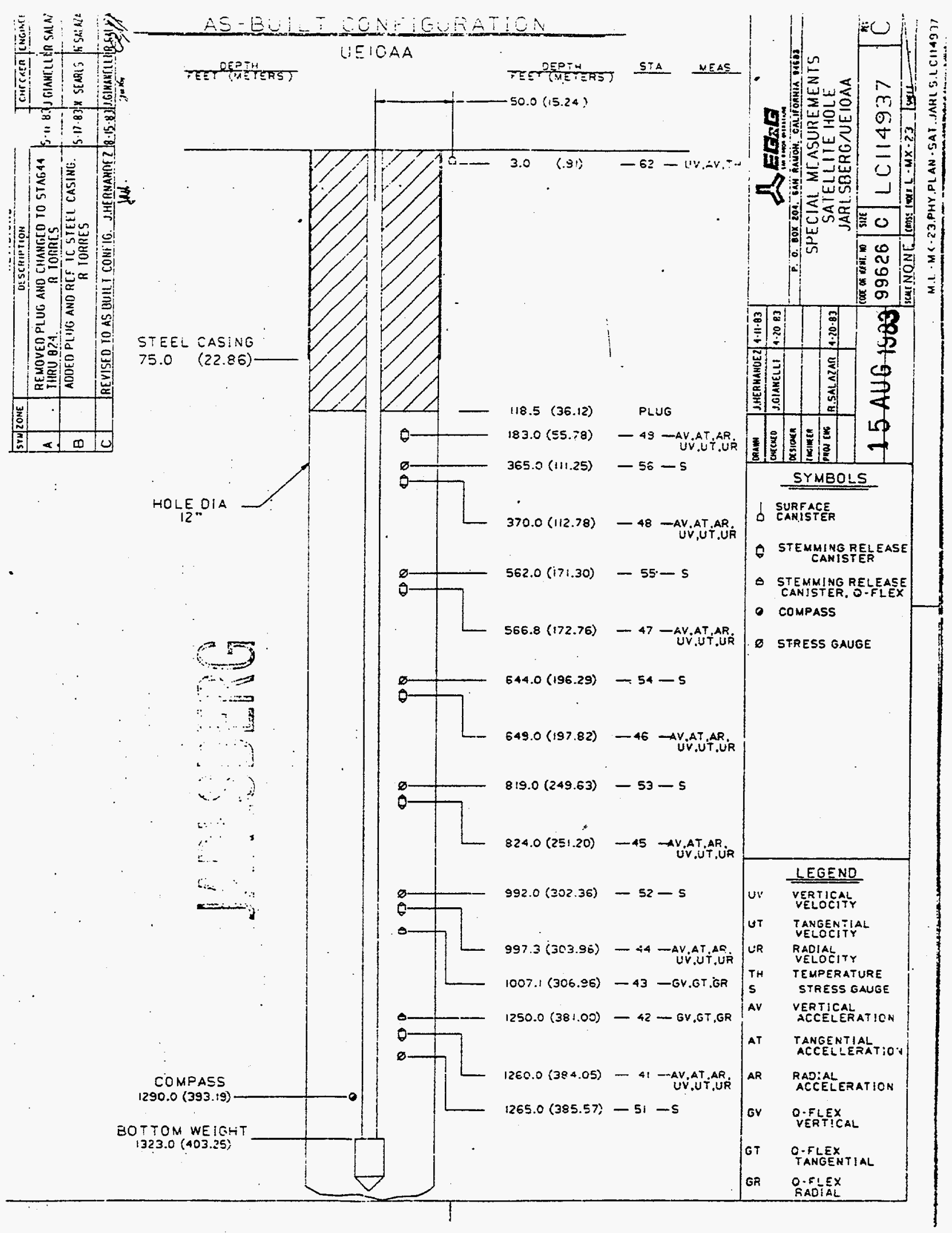

Figure 1.6 As-built instrumentation plan for the satellite hole (Ue10aa). 


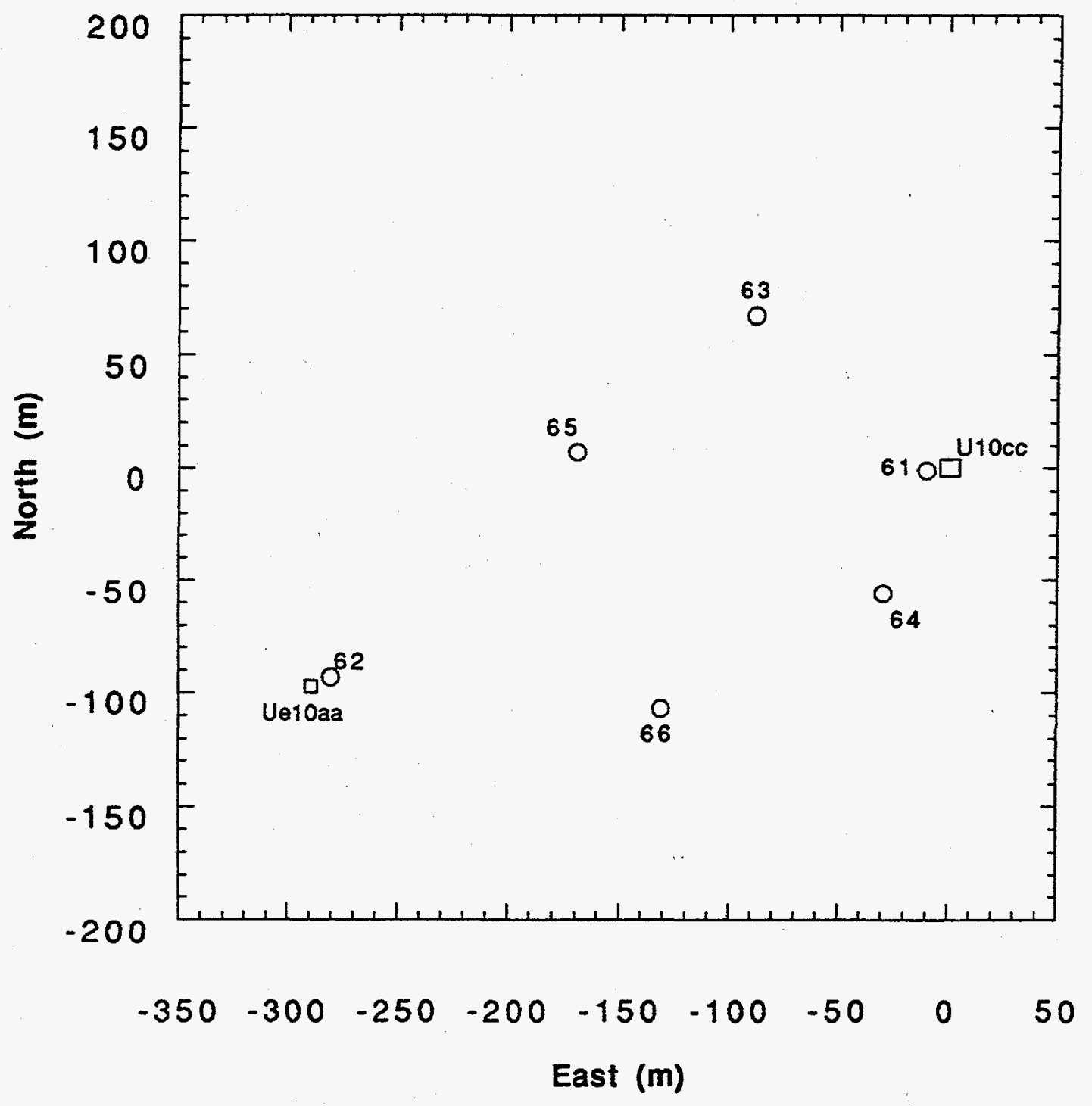

Figure 1.7 Plan view of the JARLSBERG surface array. 


\section{Emplacement}

\subsection{Pipe strain}

Pre-shot, the pipe strain gauge is used to monitor the load on the emplacement pipe. The load upon landing was 82,500 pounds.

\subsection{Plug level and temperature}

A thermistor in the top plug monitored the plug temperature history which was observed in the stemming trailer. A satisfactory plug temperature history was a requirement for the completion of stemming of the hole. As of this writing, the actual histories of the TPE plugs temperature are not available.

No other emplacement data are available except through the stemming log of Holmes \& Narver ${ }^{(3)}$. 


\section{Stemming Performance}

None of the channels serviced by the multiplexers fielded below the deepest plug survived the EMP, while both of the multiplexers above the TPE plug at the $105 \mathrm{~m}$ depth operated satisfactorily.

\subsection{Pressure and Radiation}

Stations 31 and 32 were inoperative pre-shot although they calibrated properly 60 seconds before the event. These stations were among those with multiplexers fielded below the deepest plug and thus yielded no information.

\subsection{Stress and Strain}

Stations 11-18 and 81 were among those with multiplexers fielded below the deepest plug and thus yielded no information. The only strain station which may have yielded valid data from the emplacement hole was 82 . Figure 3.1 shows the explosion-induced strain histories measured in the deepest TPE plug.

\subsection{Motion}

The three Celesco displacement gauge records are shown in Figure 3.2. Both the time around detonation and the time around collapse are covered. Stations 1 and 3 are anchored to the emplacement pipe with their free ends placed in the stemming and the top plug, respectively.

The two stemming plugs were instrumented with both vertical acceleration and velocity gauges; the data from these are shown in Figures 3.3 and 3.4. Peak amplitudes and times-ofarrival are included in the summary table 3.1. Noise levels in the recording system tend to make the displacements derived from acceleration suspect.

Characteristics of the transducers are given in tables 3.2 and 3.3. 


\subsection{Collapse}

Figure 3.4 shows the strain in the deepest plug monitored during collapse while the collapse-induced motions recorded at stations 21 and 22 are shown in figures 3.6 and 3.7.

Collapse was monitored by a cliper cable system (Station 92). Positions of the cable break are plotted as a function of time in Figure 3.8. Also included are records from the other stations showing collapse activity within the stemming column. Only the cliper data are plotted to scale, the other information merely indicates timing. Stations 21 and 22 are represented by the derived displacement while Station 82 (strain) is represented by its vertical component.

The sensor cables for stations 91 and 92 were used as "D" cables for monitoring the stemming procedures and as CLIPERs for monitoring cavity collapse. Station 92 was switched to standard CLIPER electronics at about $0.1 \mathrm{~s}$ after detonation for recording while station 91 was recorded as a "D" cable for times after detonation. Computer software for converting the " $\mathrm{D}$ " cable signal to CLIPER equivalent information has not been developed, thus the station 91 data are not presented. 

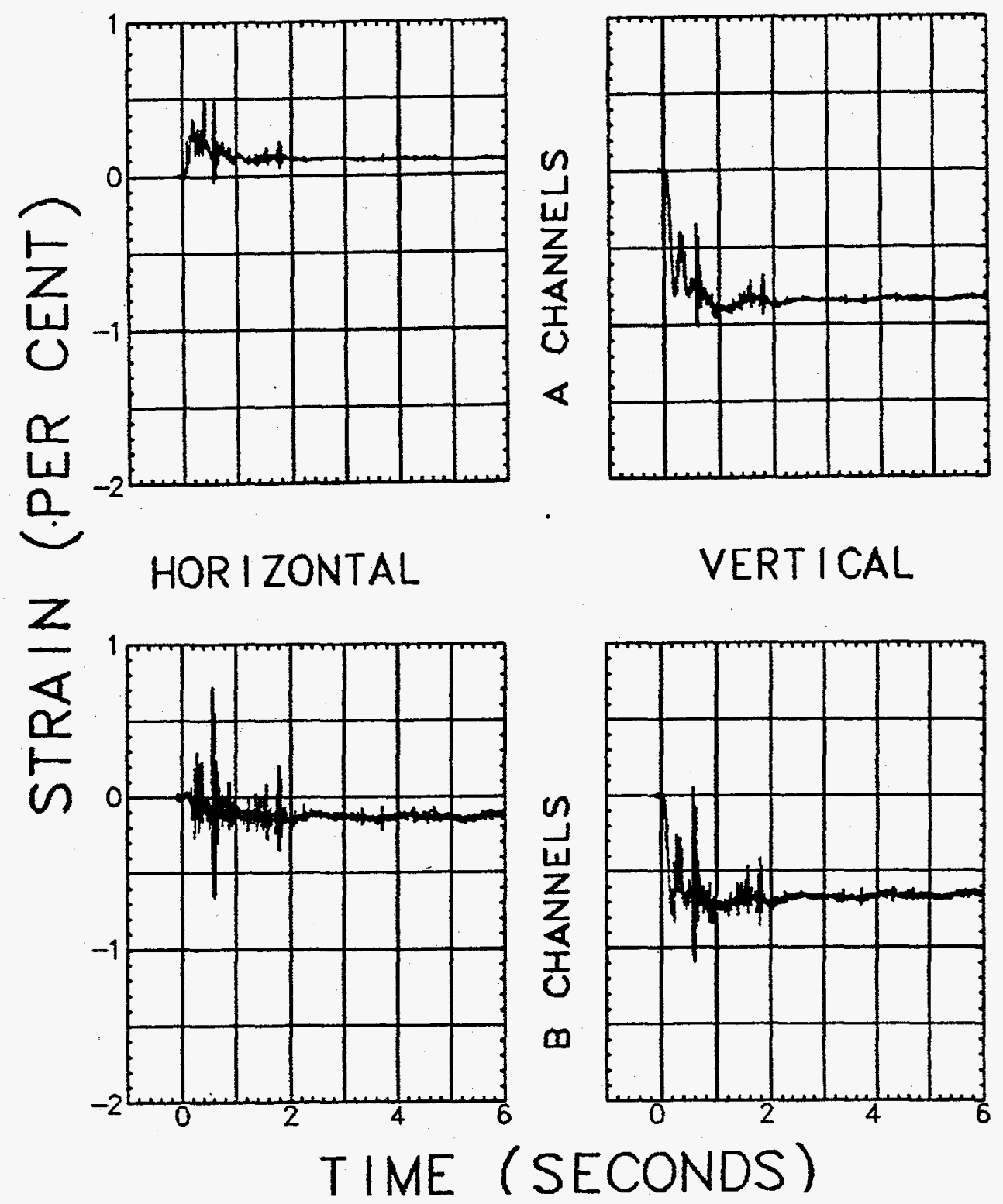

Figure 3.1 Explosion-induced horizontal and vertical strains measured in the TPE plug at a depth of $105 \mathrm{~m}$ (station 82). 


\section{JARLSBERG}

CELESCO DISPLACEMENT GAGES
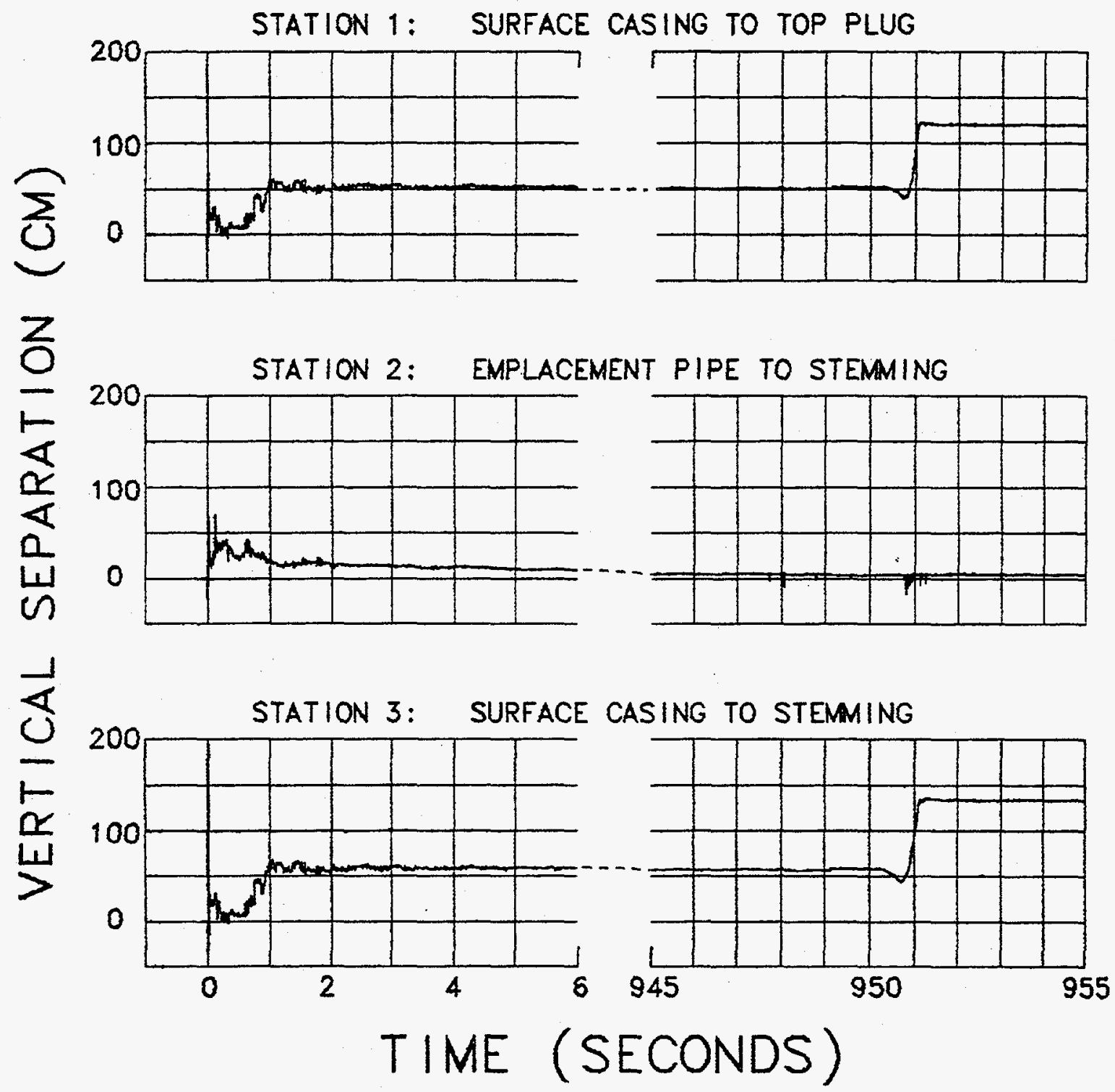

Figure 3.2. Relative displacement between surface casing, stemming and emplacement pipe, both during the explosion and subsequent collapse. 

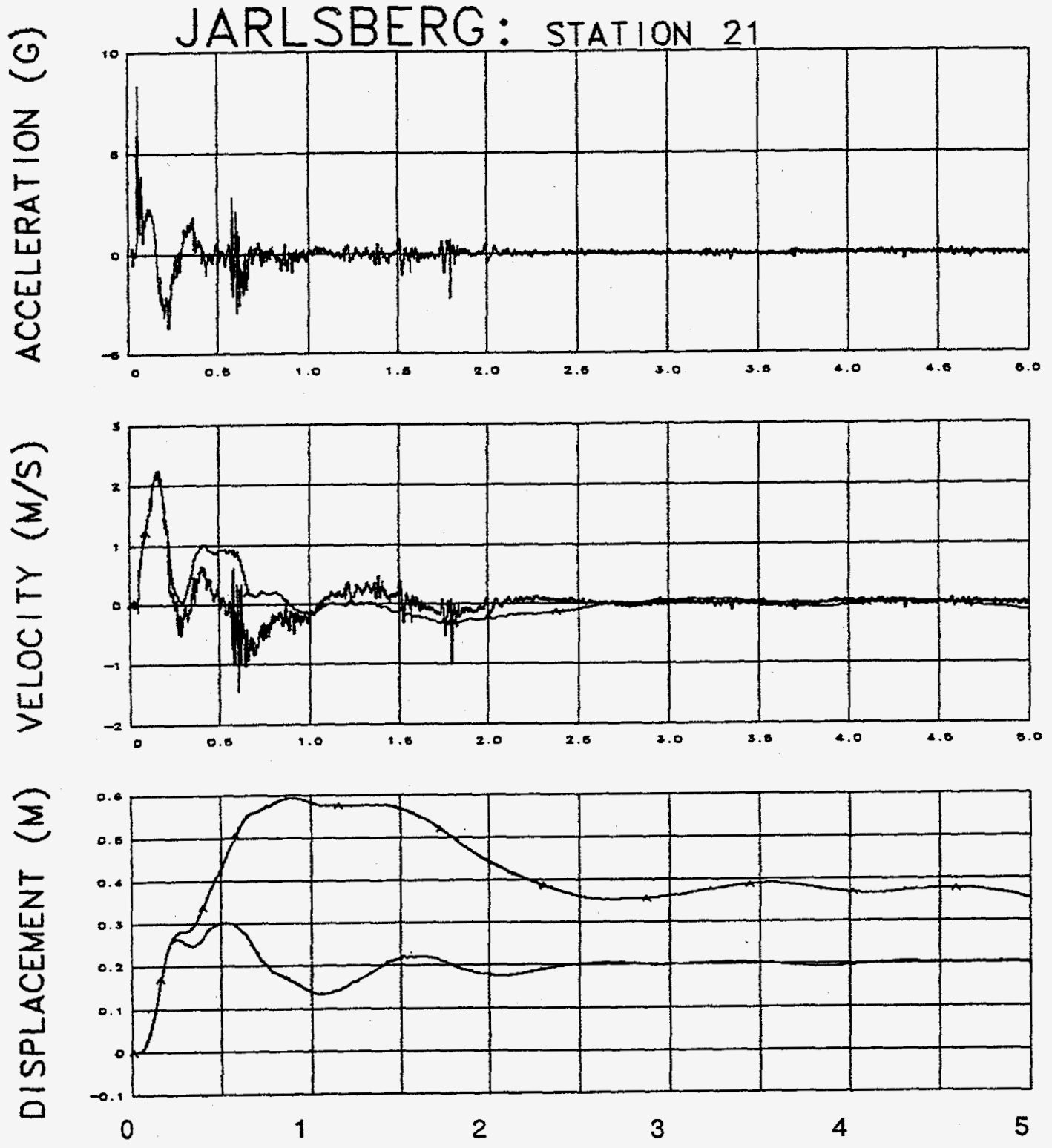

Time, s

Figure 3.3. Explosion-induced vertical motion of the deepest TPE plug at a depth of $106 \mathrm{~m}$ (Station 21). Records annotated with "A" were derived from the accelerometer. 

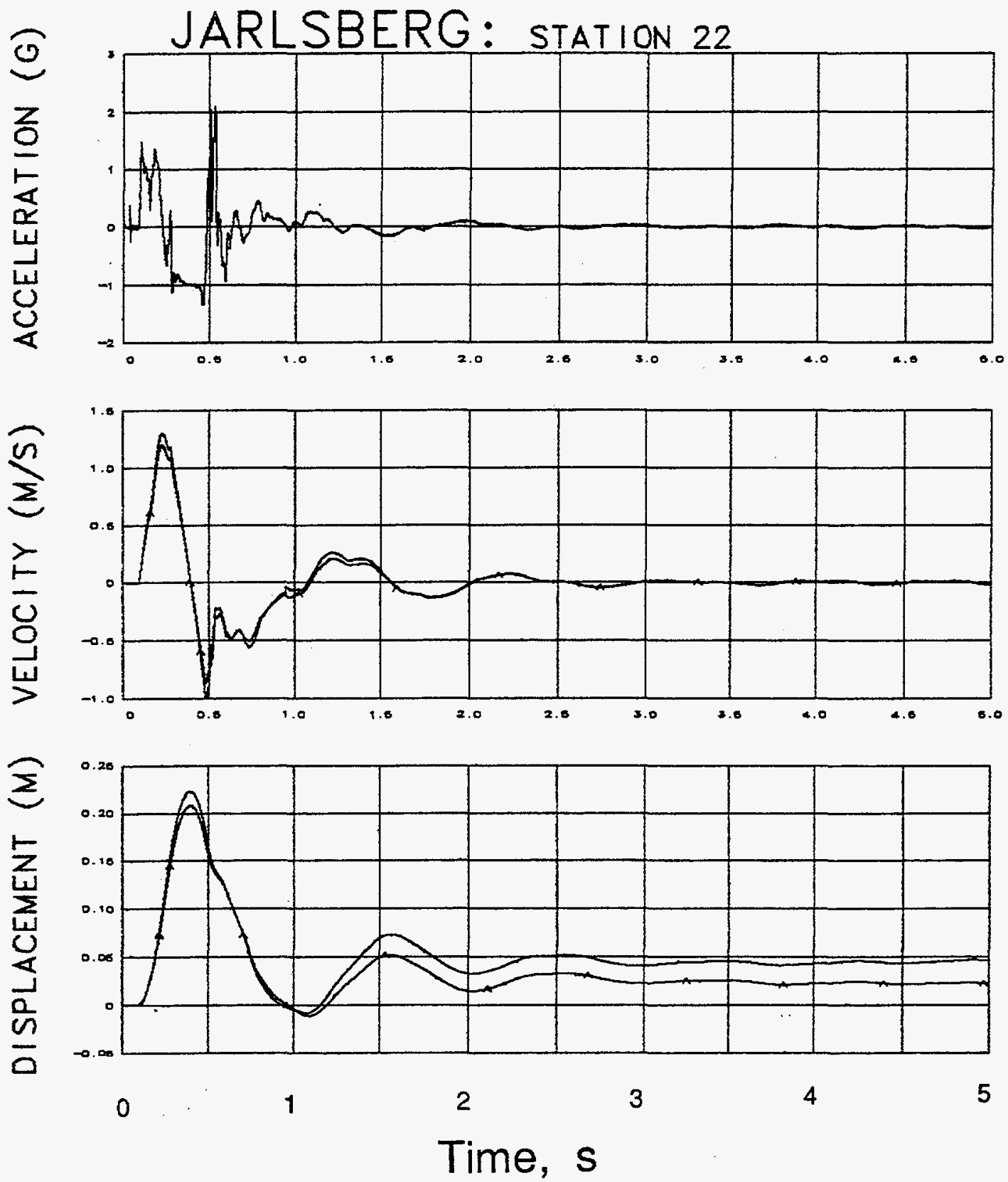

Figure 3.4. Explosion-induced vertical motion of the top TPE plug at a depth of $35 \mathrm{~m}$ (Station 22). Records annotated with " $A$ " were derived from the accelerometer. 


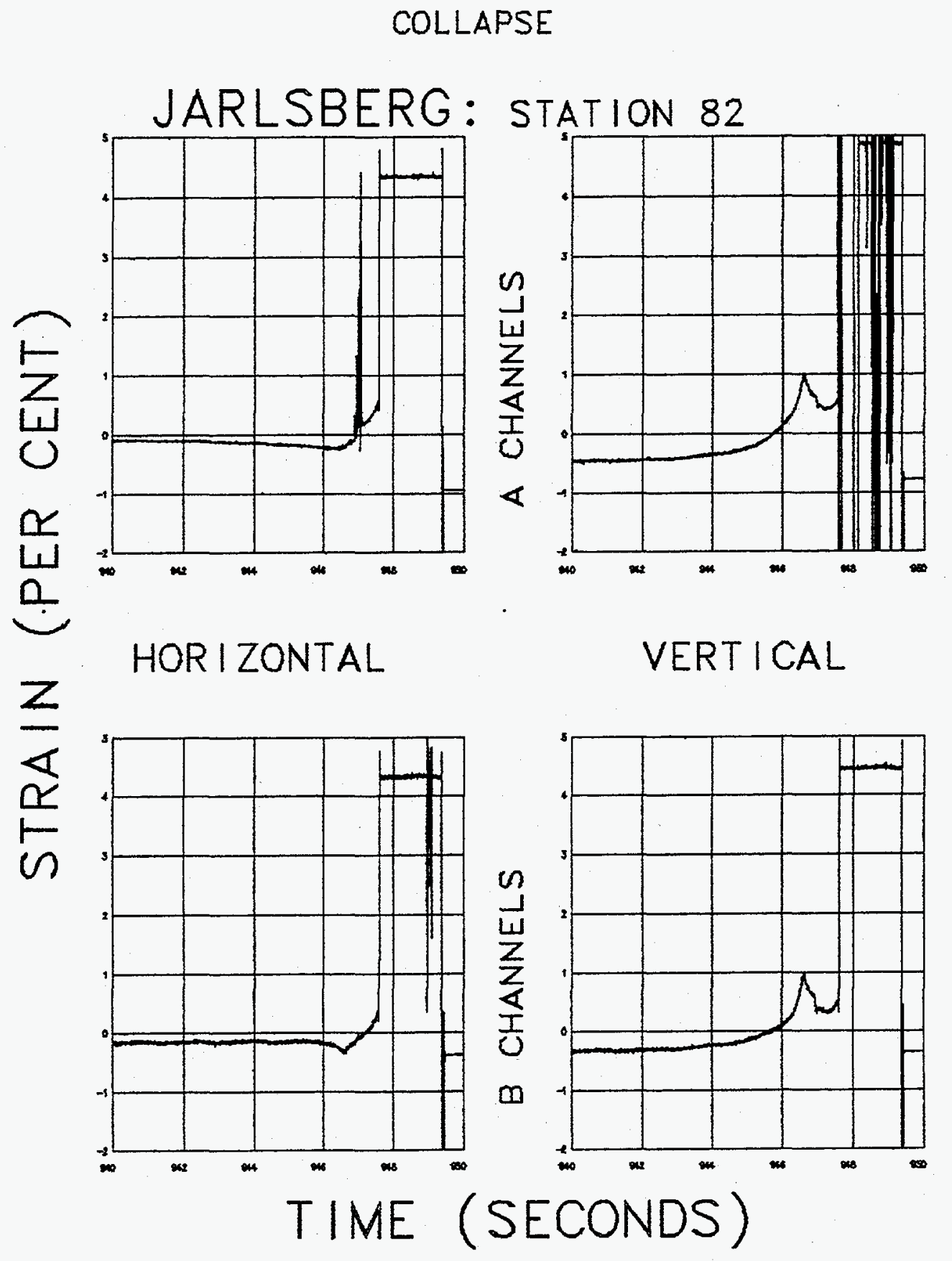

Figure 3.5. Collapse-induced horizontal and vertical strains measured in the TPE plug at a depth of $105 \mathrm{~m}$ (station 82). 

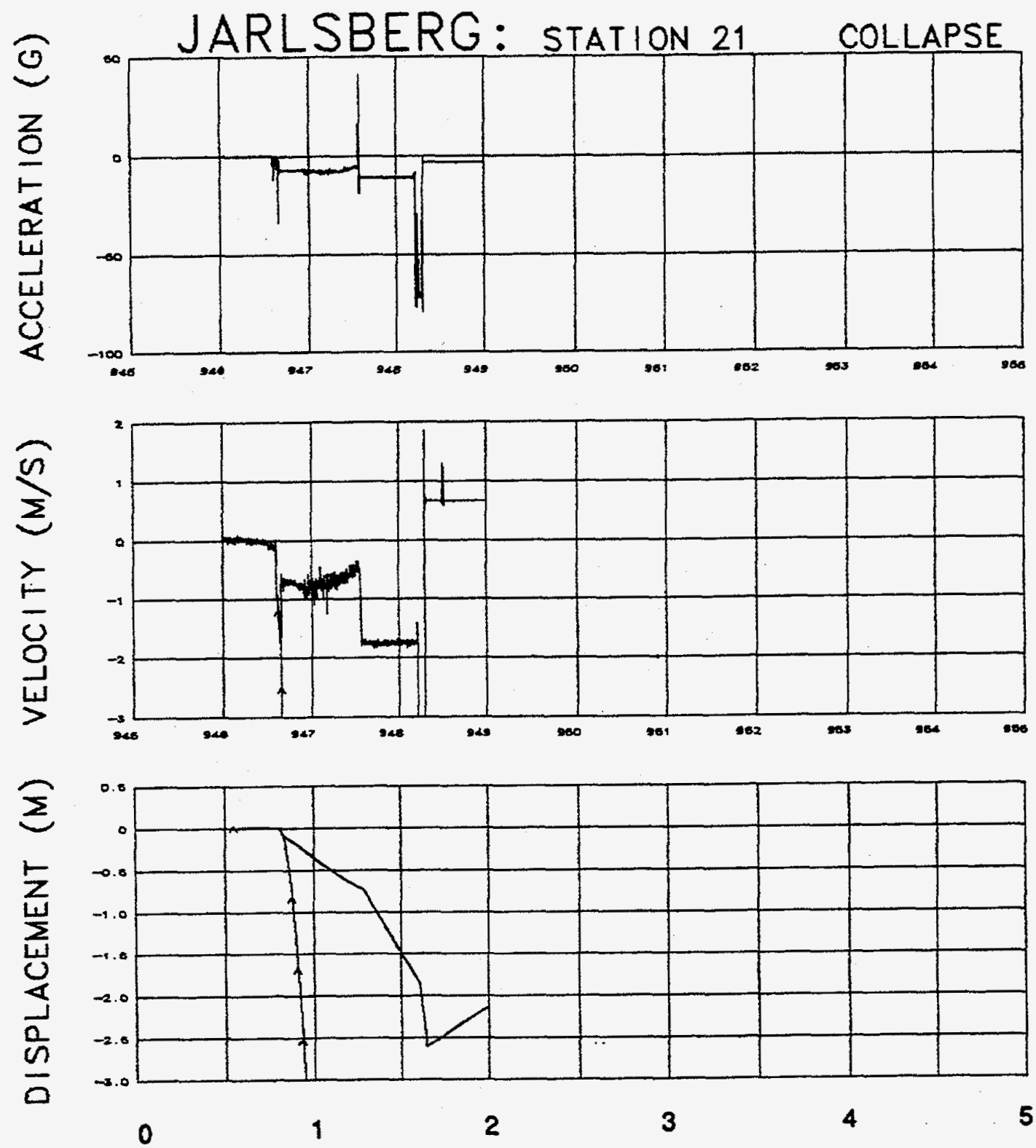

Time, $s$

Figure 3.6. Collapse-induced vertical motion of the deepest TPE plug at a depth of $106 \mathrm{~m}$ (Station 21). Records annotated with " $A$ " were derived from the accelerometer. 

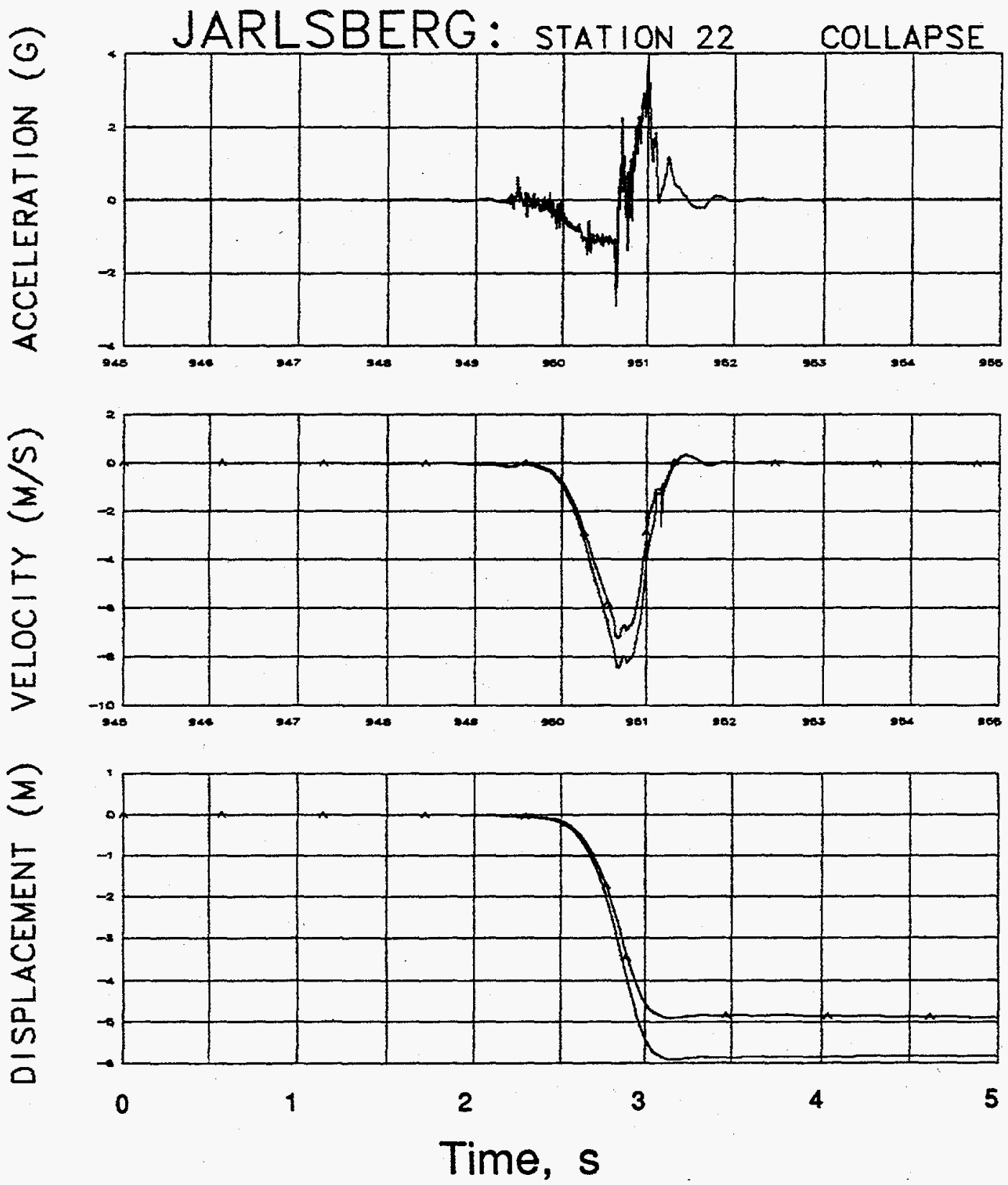

Figure 3.7. Collapse-induced vertical motion of the top TPE plug at a depth of $35 \mathrm{~m}$ (Station 22). Records annotated with " $A$ " were derived from the accelerometer. 


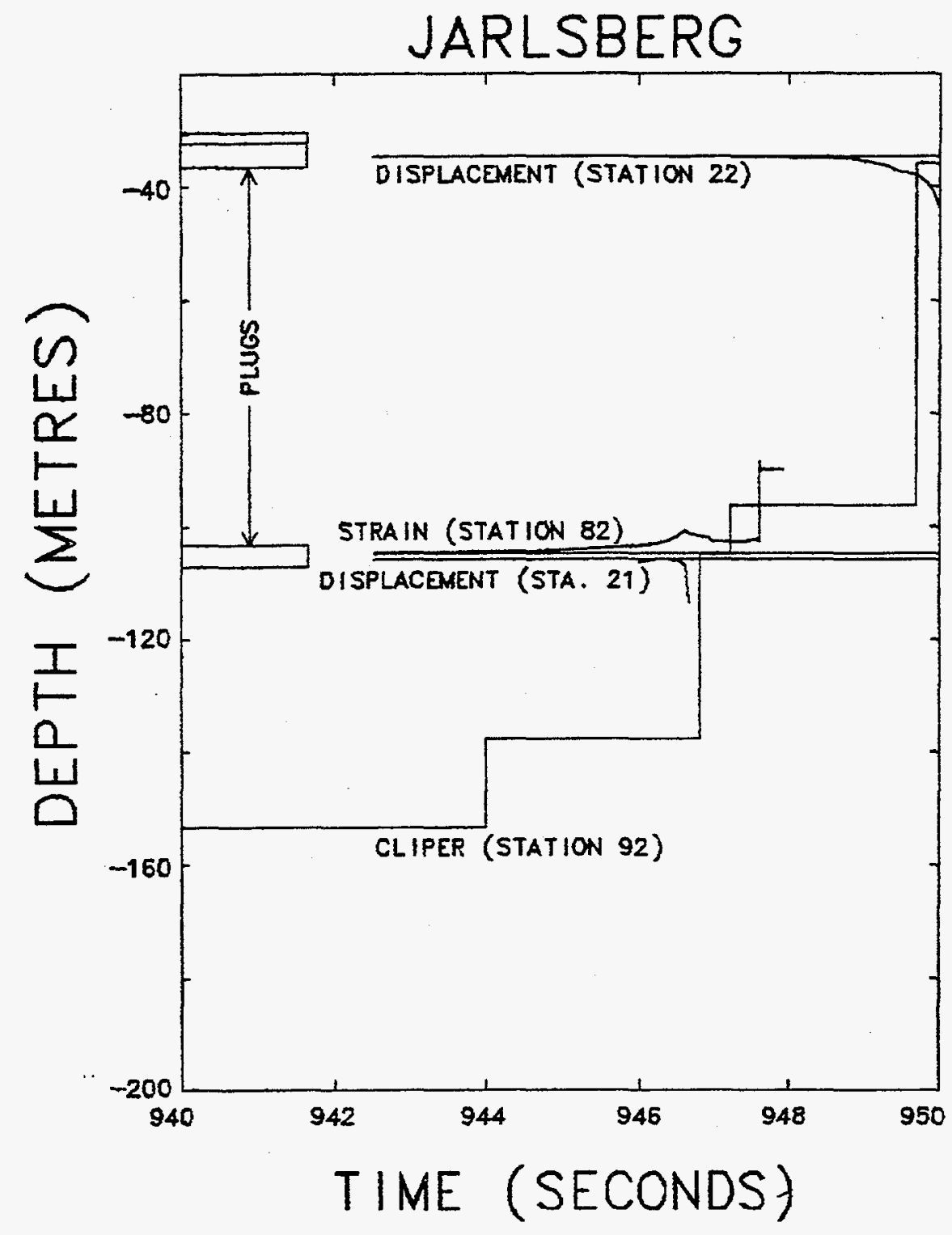

Figure 3.8. Collapse history as indicated by the CLIPER cable, motion stations in the TPE plugs, and the vertical strain measurement in the bottom plug. 


\section{Surface Motion}

See Figure 1.7 for a lay-out of the relative positions of the surface array instrumentation.

All surface stations were instrumented with vertical accelerometers and velocity gauges and each contained a supplemental accelerometer denoted "gv" to identify it as one that is usually employed as a geophone oriented in the vertical direction. All of the "gv" gauges (except at station 62) were over-ranged and thus had "clipped" peaks. When shown with the data from velocity gauges, the velocity and displacement histories derived from the standard accelerometers are annotated with an "A". The histories obtained from the geophone accelerometers are annotated with a "B". All the surface motion histories, both measured and derived are presented in figures 4.1 through 4.6. All three transducers of Station 62 remained within band and are presented in Figure 4.2. As indicated in section 1.2, the velocity transducers for stations 64,65 , and 66 all malfunctioned at zero time and the records presented are thus derived from the accelerometer histories. The accelerometer at station 63 (channel 63av) was apparently damaged by the EMP and is also excluded.

All three channels of Station 61 were processed to yield the motion during collapse, (Figure 4.7). Although the plot is not precise enough to show it, 61gv indicates a "free-fall" period (negative acceleration of close to $-1 \mathrm{~g}$ ). This channel was severely clipped (the bandwidth was $\pm 1.3 \mathrm{~g}$ ) so the integrals from this channel should not be accepted.

A summary of the explosion-induced surface motion data is included in table 3.1 and the transducer characteristics are given in tables 3.2 and 3.3. Included in table 3.1 are the horizontal azimuthal directions of propagation from the working point to the respective stations. 

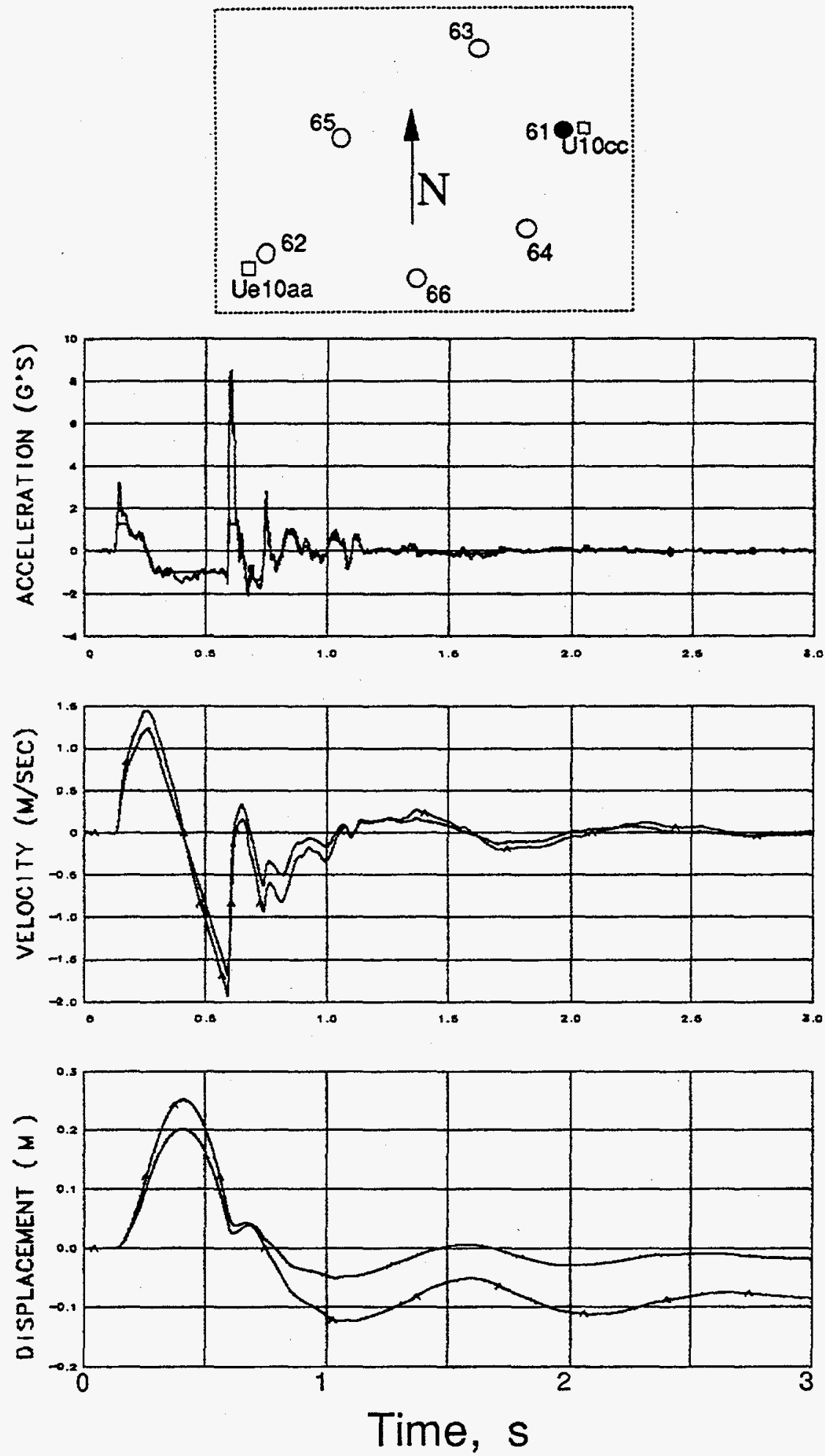

Figure 4.1 Explosion-induced vertical motion of the ground surface at a horizontal range of $10.1 \mathrm{~m}$ and azimuth of $187.0^{\circ}$ from surface ground zero (station 61). Traces annotated with "A" were derived from the accelerometer. 

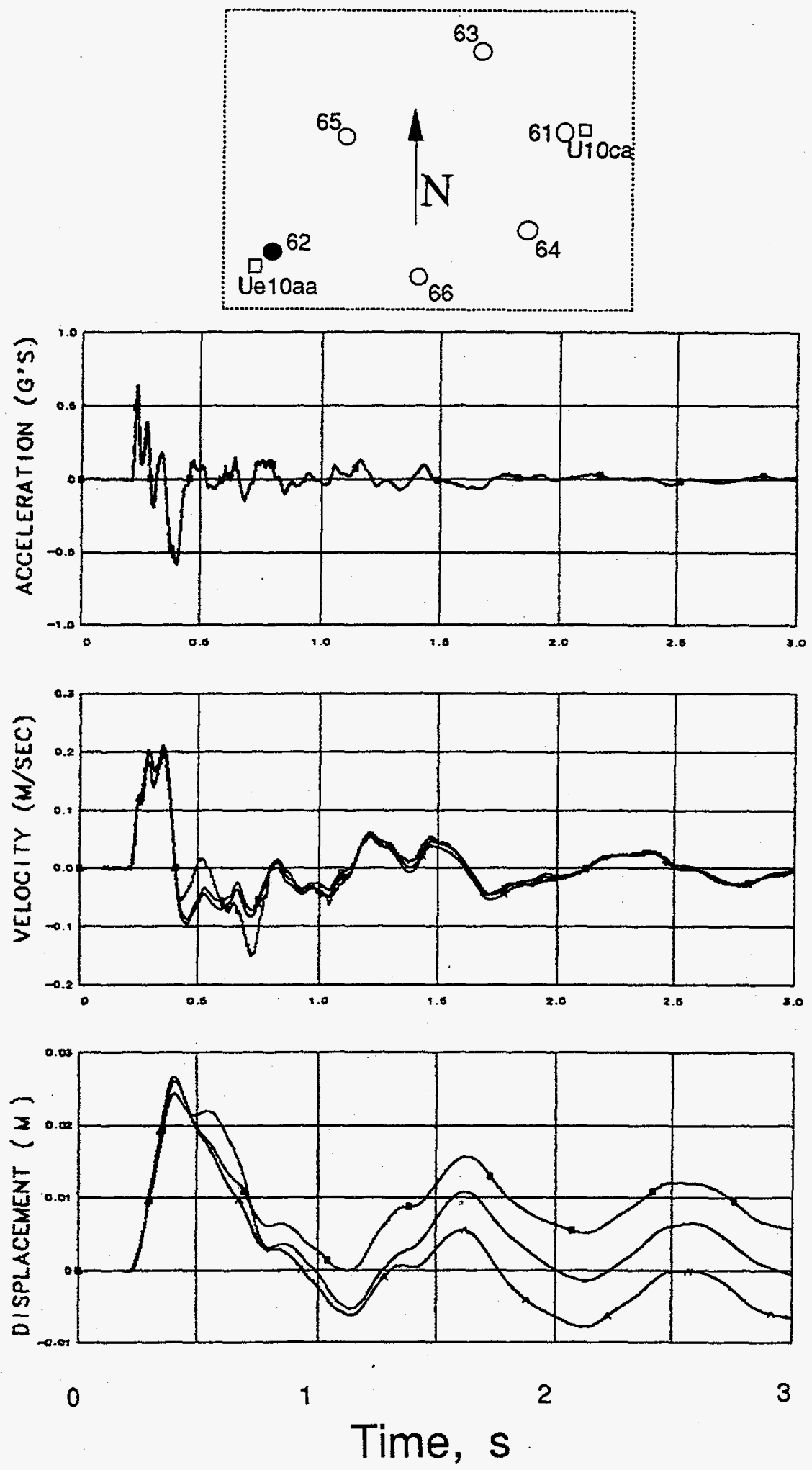

Figure 4.2. Explosion-induced vertical motion of the ground surface at a horizontal range of $295.1 \mathrm{~m}$ and azimuth of $198.4^{\circ}$ from surface ground zero (station 62). Traces annotated with "A" were derived from the accelerometer. Traces annotated with "B" were derived from the supplemental accelerometer. 

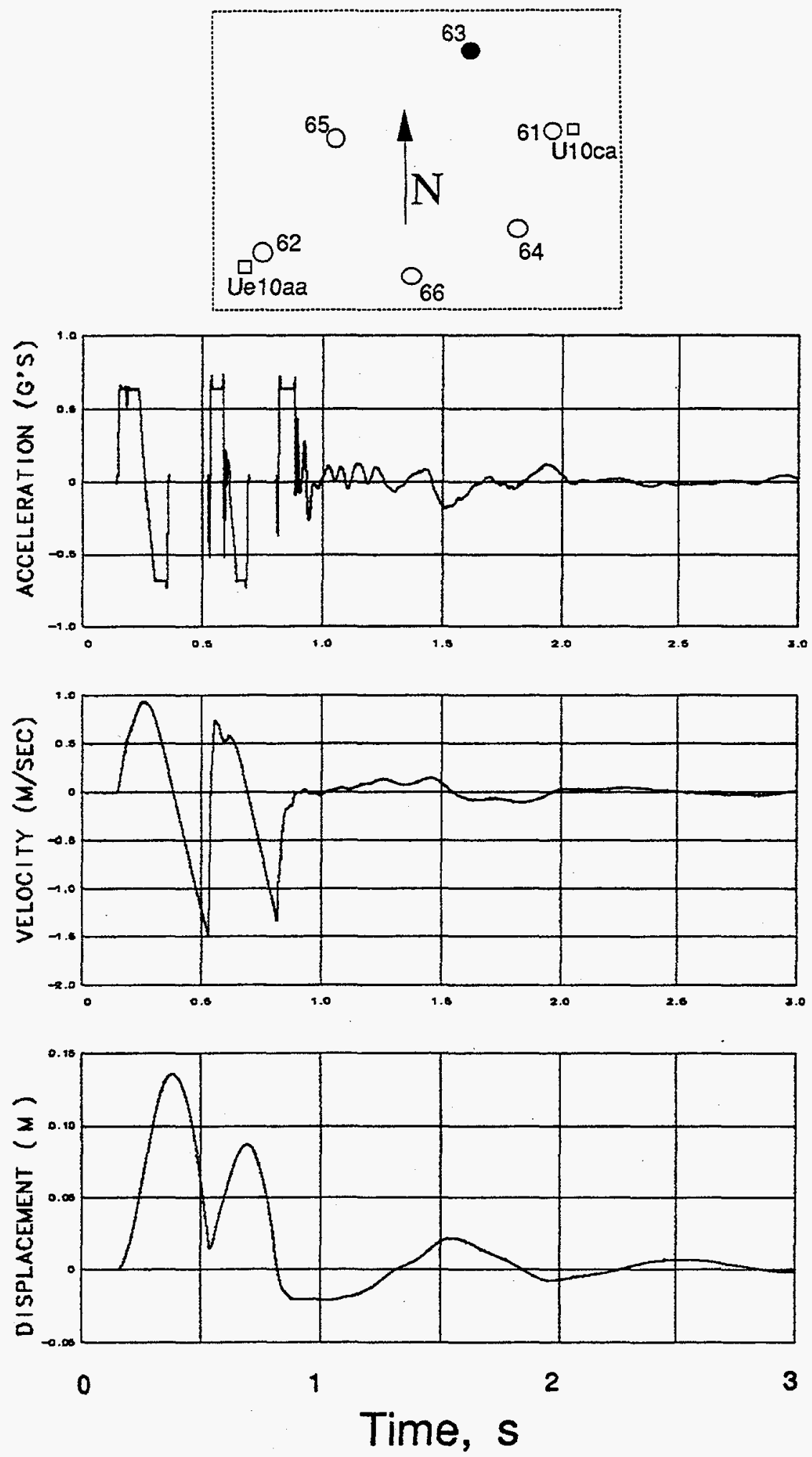

Figure 4.3. Explosion-induced vertical motion of the ground surface at a horizontal range of $110.5 \mathrm{~m}$ and azimuth of $142.8^{\circ}$ from surface ground zero (station 63). 

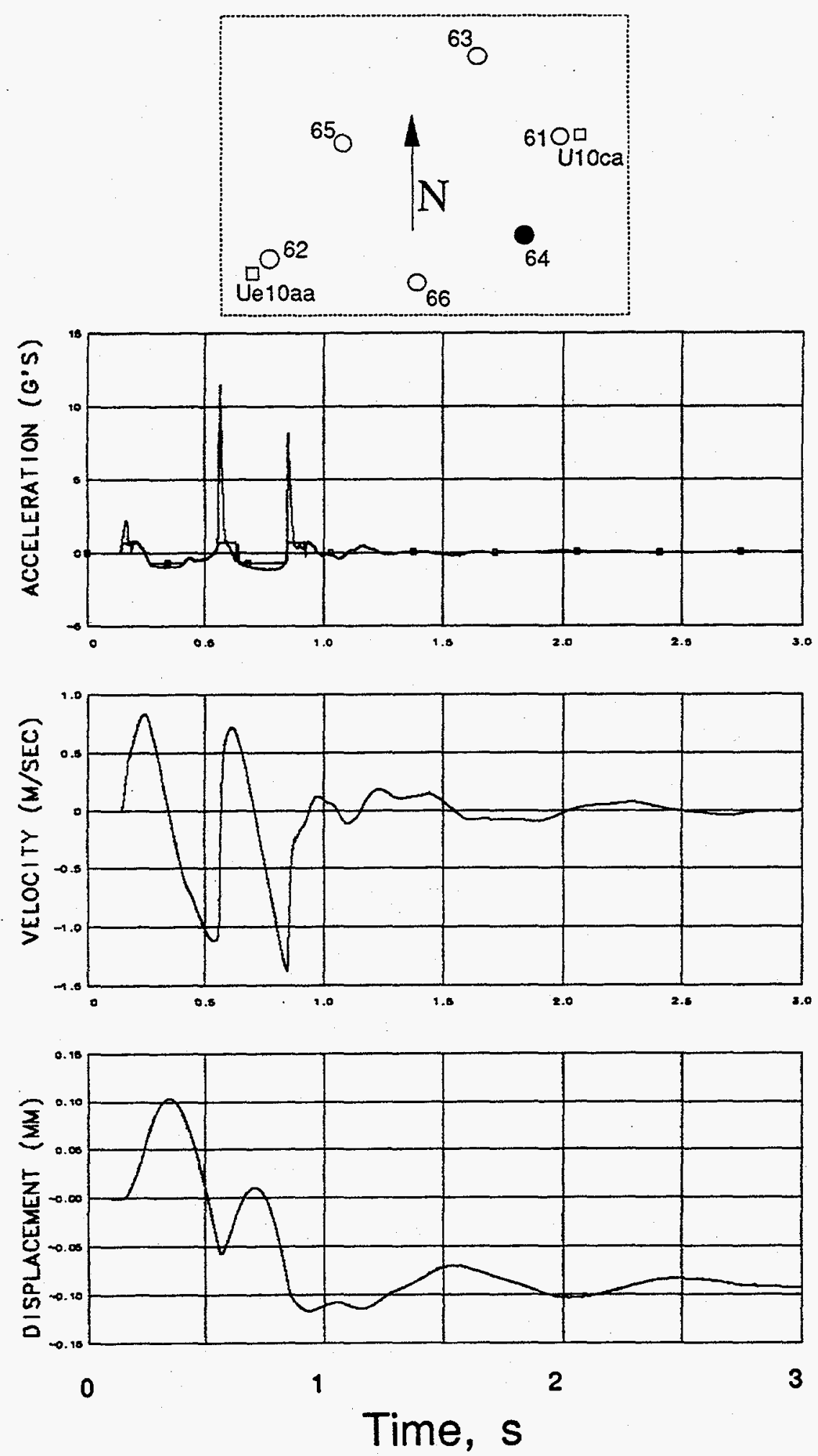

Figure 4.4. Explosion-induced vertical motion of the ground surface at a horizontal range of $63.2 \mathrm{~m}$ and azimuth of $242.7^{\circ}$ from surface ground zero (station 64). Traces annotated with "B" were derived from the supplemental accelerometer. 

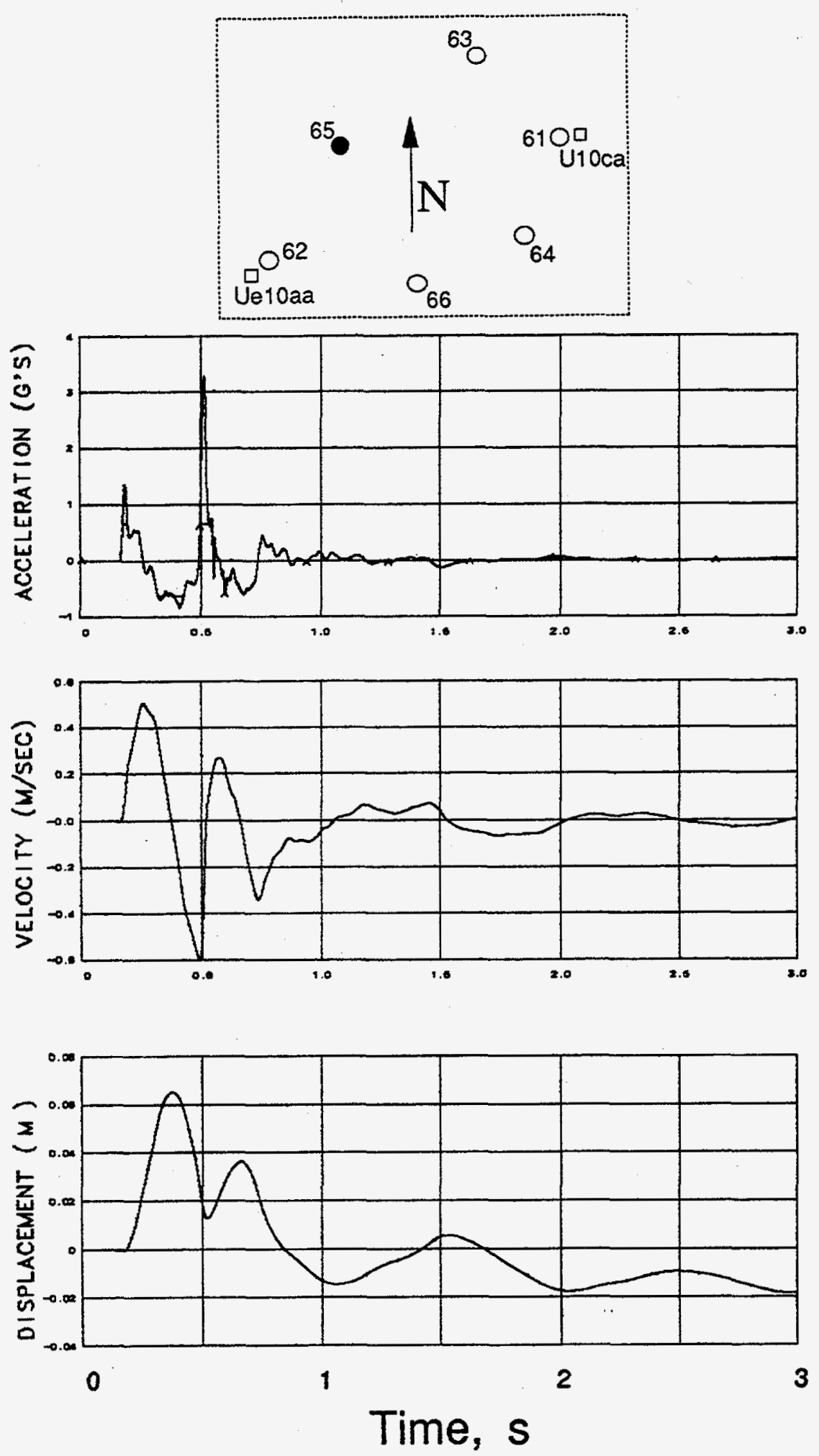

Figure 4.5 Explosion-induced vertical motion of the ground surface at a horizontal range of $180.6 \mathrm{~m}$ and azimuth of $177.7^{\circ}$ from surface ground zero (station 65 ). Traces annotated with " $\mathrm{A}$ " were derived from the supplemental accelerometer. 

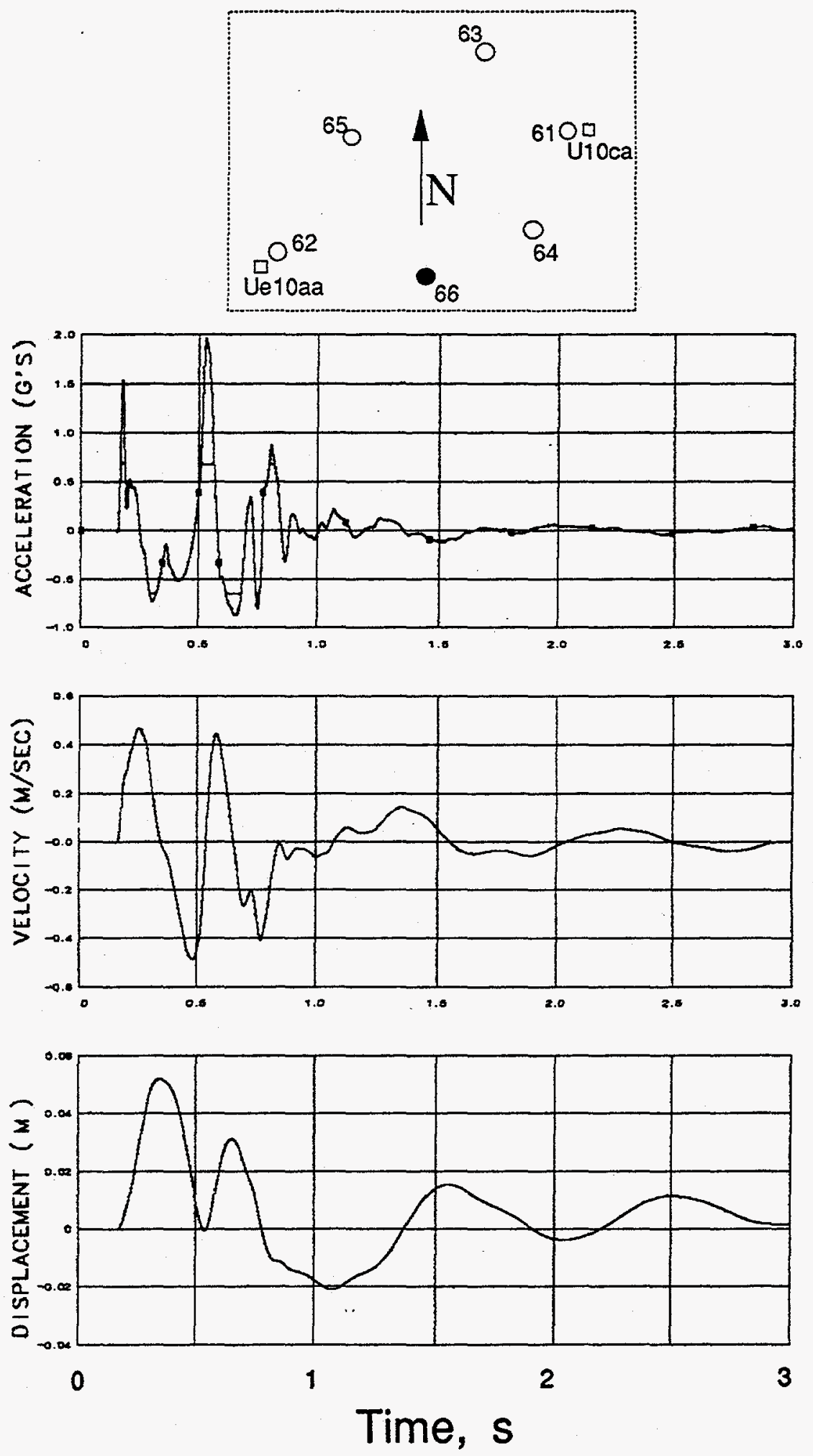

Figure 4.6 Explosion-induced vertical motion of the ground surface at a horizontal range of $169.3 \mathrm{~m}$ and azimuth of $219.3^{\circ}$ from surface ground zero (station 66 ). Traces annotated with " $\mathrm{B}$ " were derived from the supplemental accelerometer. 

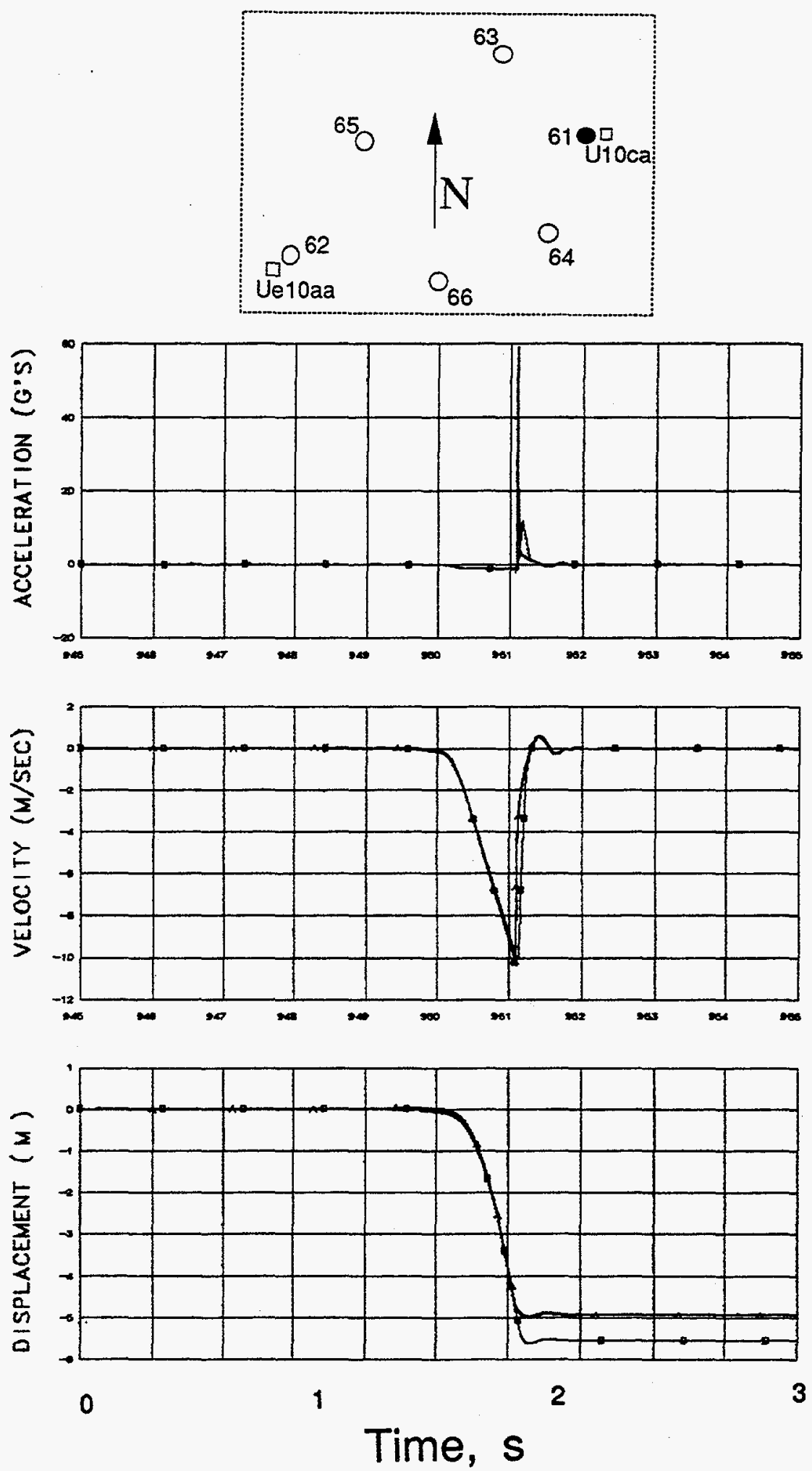

Figure 4.7. Collapse-induced vertical motion of the ground surface at a horizontal range of $10.1 \mathrm{~m}$ and azimuth of $187^{\circ}$ from surface ground zero (station 61). Traces annotated with " $A$ " were derived from the accelerometer. Traces annotated with "B" were derived from the supplemental accelerometer. 


\section{Table 3.1}

\section{Surface and Emplacement Hole Motion Summary}

\begin{tabular}{|c|c|c|c|c|c|c|c|}
\hline Gauge & $\begin{array}{l}\text { Slant } \\
\text { Range } \\
(\mathrm{m})\end{array}$ & $\begin{array}{l}\text { Azimutht } \\
\text { angle } \\
\text { (degrees) }\end{array}$ & $\begin{array}{l}\text { Arrival } \\
\text { Time } \\
\text { (ms) }\end{array}$ & $\begin{array}{c}\text { Peak } \\
\text { Acceleration } \\
\text { (g) }\end{array}$ & $\begin{array}{l}\text { Peak } \\
\text { Velocity } \\
(\mathrm{m} / \mathrm{s})\end{array}$ & $\begin{array}{c}\text { Peak } \\
\text { Displacement } \\
\text { (m) }\end{array}$ & $\begin{array}{c}\text { Residual } \\
\text { Displacement } \\
\text { (cm) }\end{array}$ \\
\hline $21 \mathrm{av}$ & 94.0 & NA & 19 (a) 45 & 8.3 & 2.25 & 0.280 & (b) \\
\hline 21 uv & & & & & 2.20 & 0.265 & 200 \\
\hline $\begin{array}{l}22 a v \\
22 u v \\
\end{array}$ & 165.4 & $\mathrm{NA}$ & $35(a), 91$ & 1.46 & $\begin{array}{l}1.20 \\
1.30\end{array}$ & $\begin{array}{l}0.207 \\
0.223\end{array}$ & $\begin{array}{l}24 \\
45\end{array}$ \\
\hline $\begin{array}{l}61 \mathrm{gv} \\
61 \mathrm{ar}\end{array}$ & $\begin{array}{c}(c) \\
210.6\end{array}$ & 187.0 & 125 & $2.9,12.1^{(d)}$ & 1.35 & 0.234 & (b) \\
\hline 61uv & & & & & 1.24 & 0.204 & -15 \\
\hline $\begin{array}{l}62 g v \\
62 a v \\
62 u v\end{array}$ & 324.7 & 198.4 & $\begin{array}{c}166,241 \\
213\end{array}$ & $\begin{array}{l}0.630 \\
0.628\end{array}$ & $\begin{array}{l}0.200 \\
0.203 \\
0.181\end{array}$ & $\begin{array}{l}0.0260 \\
0.0265 \\
0.0243\end{array}$ & $\begin{array}{c}9 \\
-2 \\
2\end{array}$ \\
\hline $\begin{array}{l}63 g v \\
63 a v \\
63 u v\end{array}$ & $\begin{array}{c}(c) \\
242.3\end{array}$ & 142.8 & 145 & (e) & 0.830 & 0.136 & 1 \\
\hline $\begin{array}{l}64 \mathrm{gv} \\
64 \mathrm{av}\end{array}$ & $\begin{array}{c}(c) \\
242.3\end{array}$ & 242.7 & 135 & $2.15,11.5$ (d) & $\begin{array}{c}3.75 \\
0.820\end{array}$ & $\begin{array}{c}2.00 \\
0.103\end{array}$ & $\begin{array}{l}\text { (b) } \\
-90\end{array}$ \\
\hline 64uv & (e) & & - & - & & & \\
\hline $\begin{array}{l}65 \mathrm{gv} \\
65 \mathrm{av} \\
65 \mathrm{uv} \\
\end{array}$ & $\begin{array}{c}(c) \\
278.3 \\
(e)\end{array}$ & 177.7 & 166 & $1.36,3.27(d)$ & $\begin{array}{l}0.505 \\
1.77 \\
\end{array}$ & 0.065 & -17 \\
\hline $\begin{array}{l}66 \mathrm{gv} \\
66 \mathrm{av} \\
66 \mathrm{uv}\end{array}$ & $\begin{array}{c}(c) \\
278.5 \\
(e)\end{array}$ & 219.3 & 154 & $1.53,1.95(\mathrm{~d})$ & 0.465 & 0.052 & 3 \\
\hline $\begin{array}{l}\text { t Hori } \\
\text { (a) emp } \\
\text { (b) inval } \\
\text { (c) peak } \\
\text { (d) slap- } \\
\text { (e) malf }\end{array}$ & $\begin{array}{l}\text { ntal an } \\
\text { ement } \\
\text { data } \\
\text { nvalid: } \\
\text { wn pe } \\
\text { ction; }\end{array}$ & $\begin{array}{l}\text { of prop } \\
\text { se-induc } \\
\text { ta out } 0\end{array}$ & $\begin{array}{l}\text { tion fron } \\
\text { arrival } \\
\text { ad }\end{array}$ & working p & ero $=$ & & \\
\hline
\end{tabular}


Table 3.2

Surface Array \& Emplacement Hole Accelerometer Characteristics

\begin{tabular}{ccccc} 
Gauge & $\begin{array}{c}\text { Natural } \\
\text { Frequency } \\
(\mathrm{Hz})\end{array}$ & $\begin{array}{c}\text { Damping } \\
\text { Ratio }\end{array}$ & $\begin{array}{c}\text { System } \\
\text { Range } \\
(\mathrm{g})\end{array}$ & type \\
\hline $21 \mathrm{av}$ & $\mathrm{NA}$ & $\mathrm{NA}$ & 80 & $\mathrm{vr}$ \\
\hline $22 \mathrm{av}$ & 410 & 0.65 & 16 & $\mathrm{vr}$ \\
\hline $61 \mathrm{av}$ & 570 & 0.65 & 30.0 & $\mathrm{vr}$ \\
$61 \mathrm{gv}$ & 253 & $\mathrm{NA}$ & 1.0 & $\mathrm{pr}$ \\
\hline $62 \mathrm{av}$ & 260 & 0.62 & 3.0 & $\mathrm{vr}$ \\
$62 \mathrm{gv}$ & 250 & $\mathrm{NA}$ & 0.5 & $\mathrm{pr}$ \\
\hline $63 \mathrm{av}$ & 267 & 0.65 & 4.0 & $\mathrm{vr}$ \\
$63 \mathrm{gv}$ & 250 & $\mathrm{NA}$ & 0.5 & $\mathrm{pr}$ \\
\hline $64 \mathrm{av}$ & 260 & 0.65 & 4.0 & $\mathrm{pr}$ \\
$64 \mathrm{gv}$ & 252 & NA & 0.5 & $\mathrm{vr}$ \\
\hline $65 \mathrm{av}$ & 170 & 0.60 & 3.0 & $\mathrm{pr}$ \\
\hline $65 \mathrm{gv}$ & 254 & NA & 0.5 & $\mathrm{vr}$ \\
\hline $66 \mathrm{av}$ & 170 & 0.70 & 3.0 & $\mathrm{pr}$ \\
\hline $66 \mathrm{gv}$ & 253 & NA & 0.5 & \\
\hline
\end{tabular}

$\dagger_{\mathrm{pr}}=$ Piezoresitive; $\mathrm{vr}=$ variable reluctance 


\section{Table 3.3}

Surface Array \& Emplacement Hole Velocimeter Characteristics

\begin{tabular}{cccccc} 
Gauge & $\begin{array}{c}\text { Natural } \\
\text { Frequency } \\
(\mathrm{Hz})\end{array}$ & $\begin{array}{c}\text { Time to } 0.5 \\
\text { Amplitude } \\
(\mathrm{s})\end{array}$ & $\begin{array}{c}\text { Calibration } \\
\text { Temperature } \\
\left({ }^{\circ} \mathrm{C}\right)\end{array}$ & $\begin{array}{c}\text { Operate } \\
\text { Temperature } \\
\left({ }^{\circ} \mathrm{C}\right)\end{array}$ & $\begin{array}{c}\text { System } \\
\text { Range } \\
(\mathrm{m} / \mathrm{s})\end{array}$ \\
\hline 21uv & NA & 11.3 & 24.2 & NA & 16.0 \\
\hline 22uv & 3.558 & 7.30 & 23.31 & 42.17 & 8.0 \\
\hline 61 uv & 3.473 & 9.63 & 23.52 & 23.30 & 9.0 \\
\hline 62 uv & 3.519 & 8.61 & 24.46 & 22.37 & 2.0 \\
\hline 63 uv & 3.558 & 9.00 & 23.53 & 22.05 & 3.0 \\
\hline 64 uv & 3.645 & 7.94 & 23.68 & 21.32 & 3.0 \\
\hline 65 uv & 3.450 & 9.71 & 24.02 & 20.89 & 2.0 \\
\hline 66 uv & 3.606 & 8.05 & 24.90 & 19.71 & 2.0 \\
\hline
\end{tabular}




\section{Satellite Hole (Free-Field) Measurements}

\subsection{Motion}

Data from all of the reporting stations are seen in Figures 5.1 through 5.21. Stations 42 and 43 were lost before the event and thus are not shown.

A summary of the explosion-induced free-field motion data is included in Table 5.1. Tables 5.2 and 5.3 list the characteristics of the motion transducers fielded in the satellite hole U10aa.

\subsection{Stress (soil pressure)}

Only station 54 appeared operational, however the signals received from stations 5154 are shown in figure 5.22. Stations 55 and 56 were inoperative pre-shot and not recorded. 

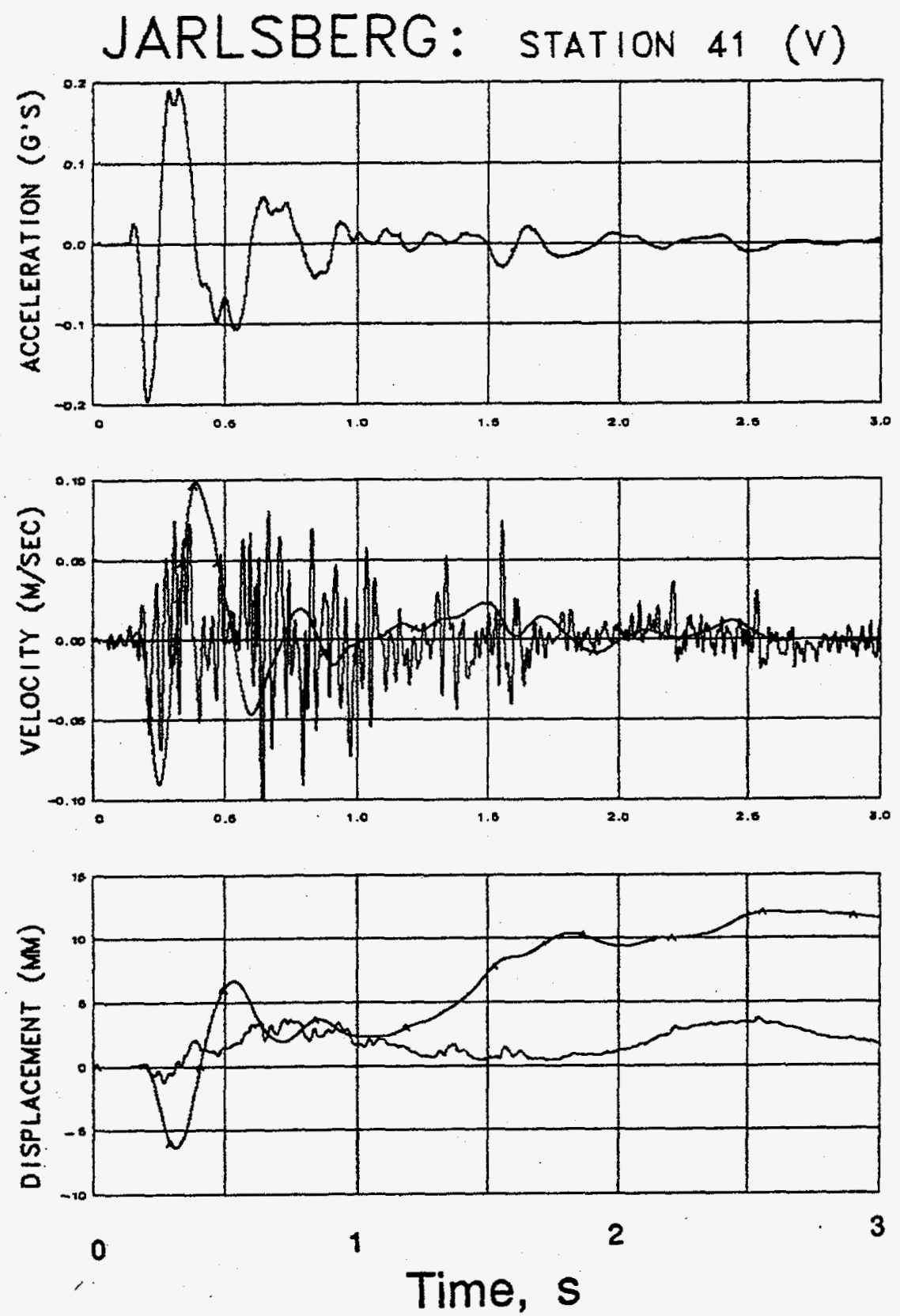

Figure 5.1 Explosion-induced vertical motion at a depth of $384 \mathrm{~m}$ in hole Ue10aa (station 41). Traces annotated with " $A$ " were derived from the accelerometer. 

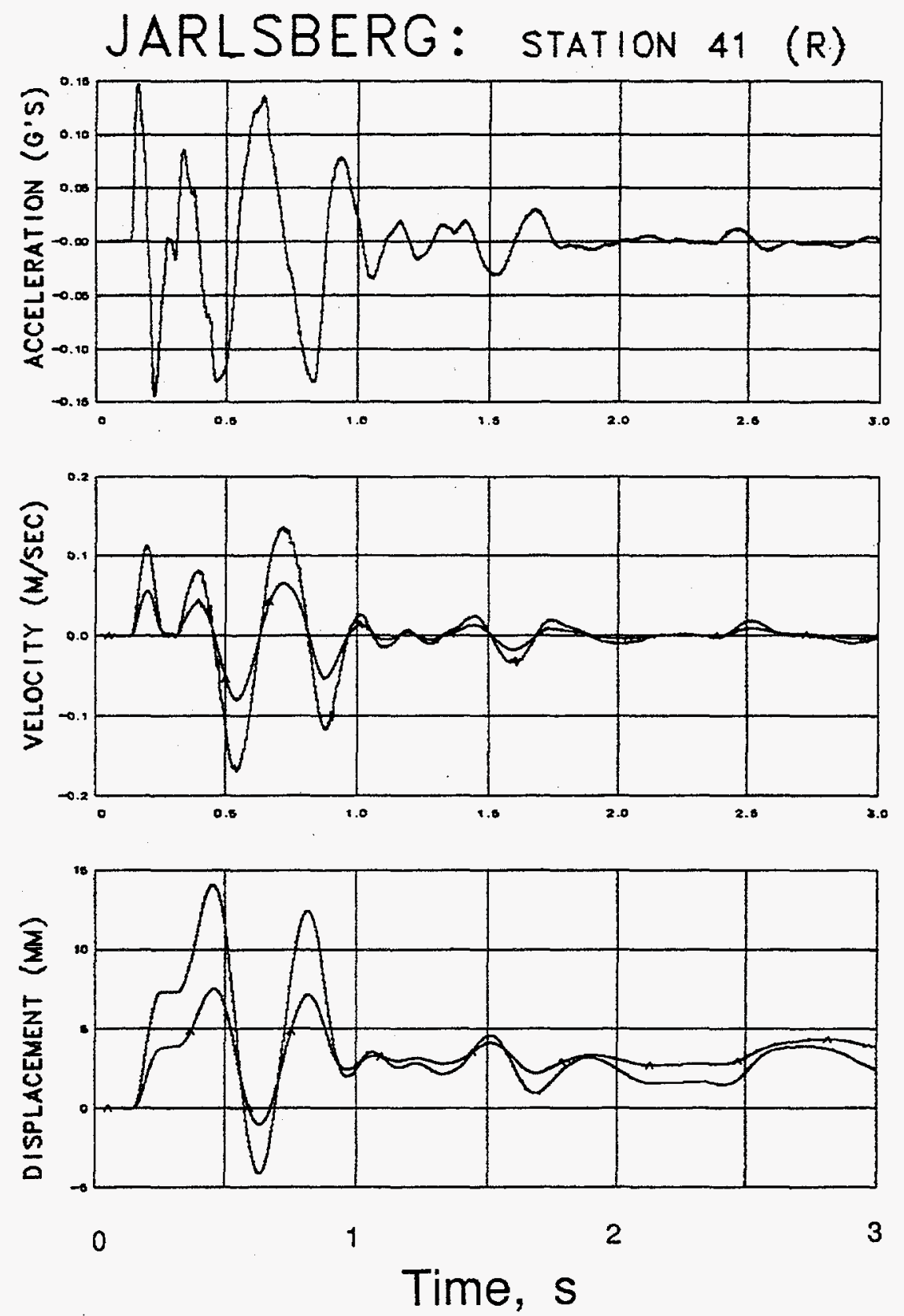

Figure 5.2 Explosion-induced radial-horizontal motion at a depth of $384 \mathrm{~m}$ in hole Ue10aa (station 41). Traces annotated with "A" were derived from the accelerometer. 
$\frac{\pi}{0}$
$\stackrel{0}{5}$
0
0
$\omega$

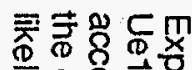

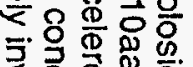

产

홍 홍

콩ㅇㅇㅇ

F

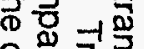

을

$\rightarrow \overrightarrow{0}$

要骂

言兽

70

ज्ञ

ऽ

象 要

击

గ్ర

잉

응 융

उ훙. 물

옹응

$\cong$ vo

ॠ

क.

Q $0^{\circ}$

ए人

을 음

is

क
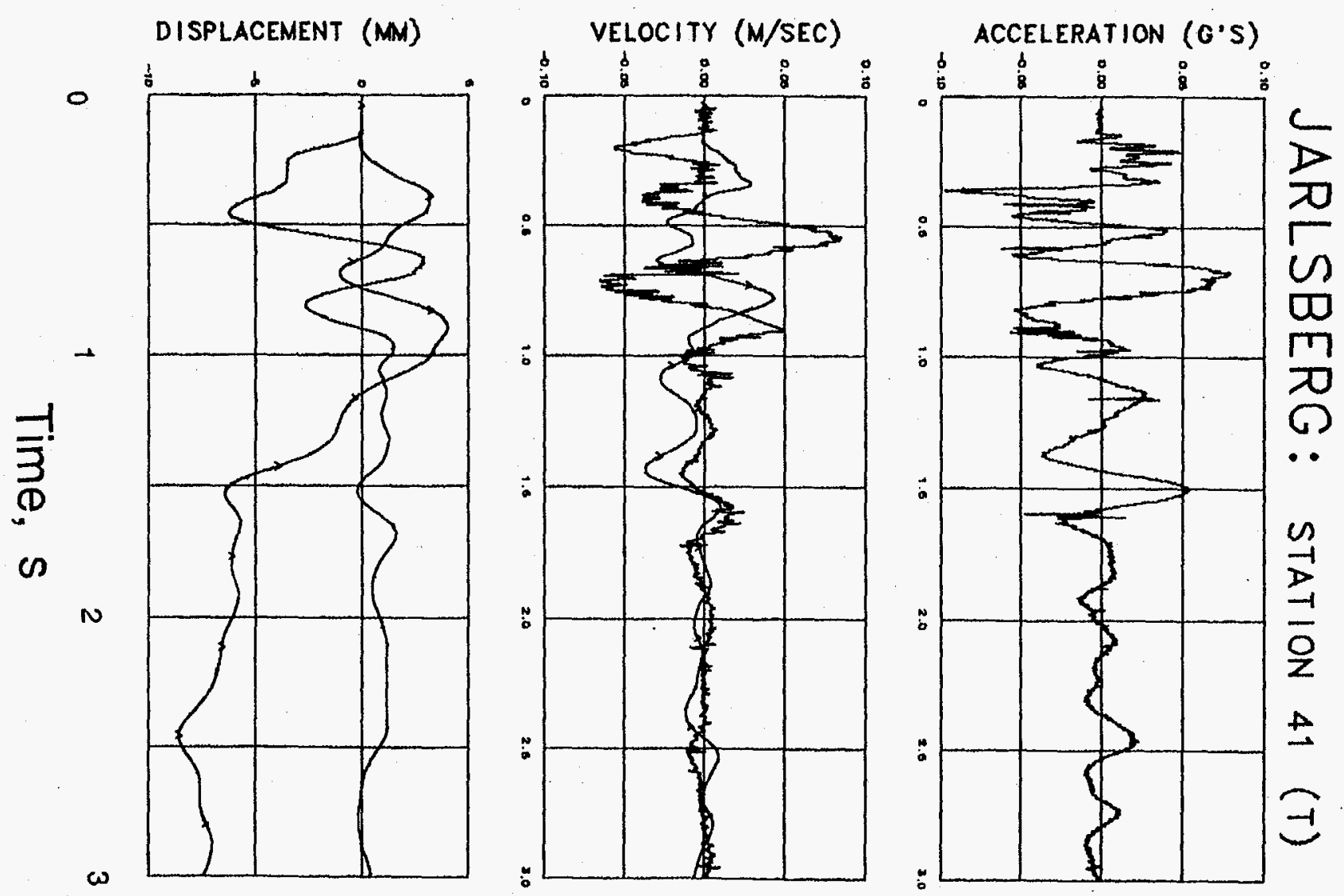

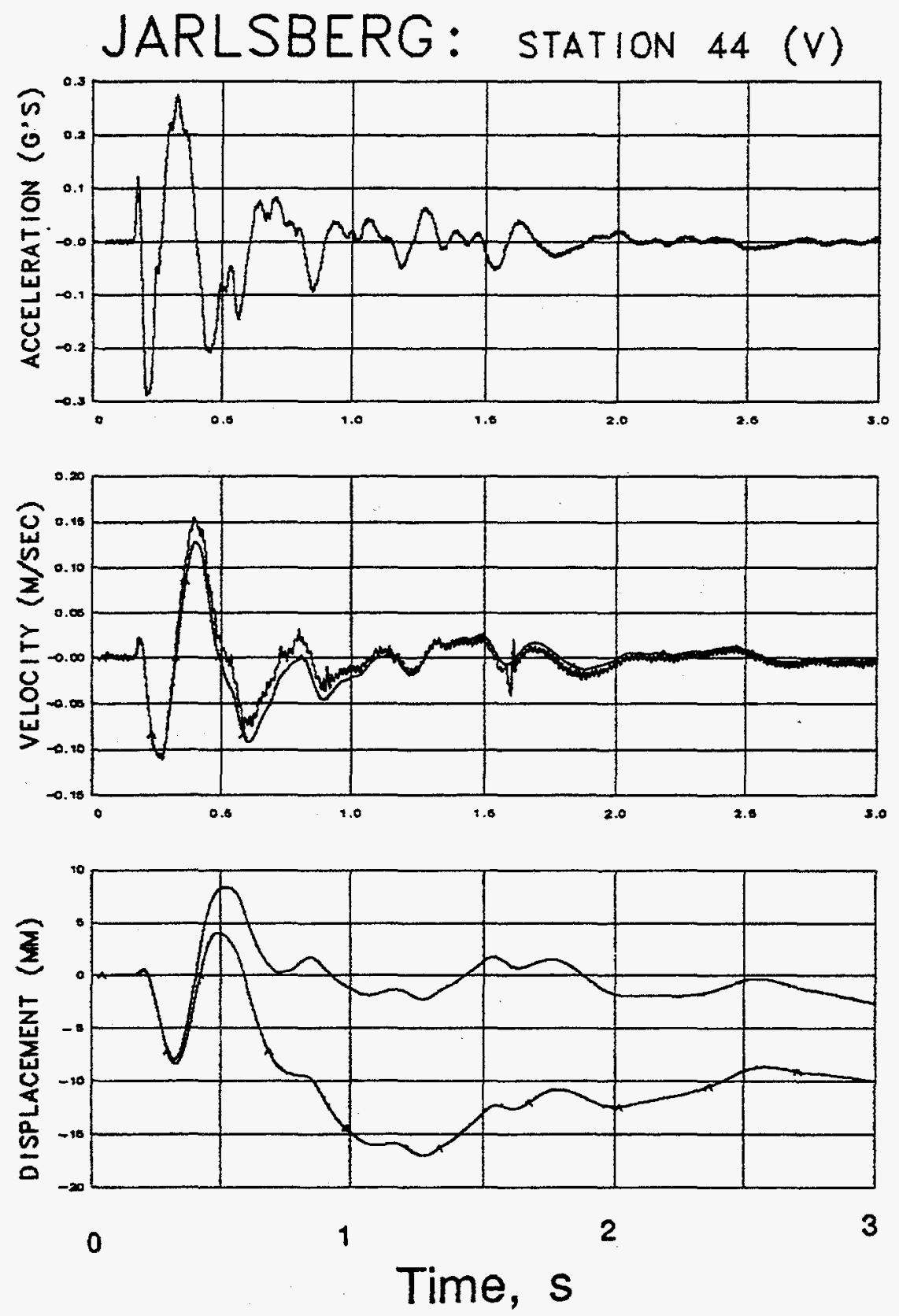

Figure 5.4 Explosion-induced vertical motion at a depth of $304 \mathrm{~m}$ in hole Ue 10aa (station 44). Traces annotated with "A" were derived from the accelerometer. 

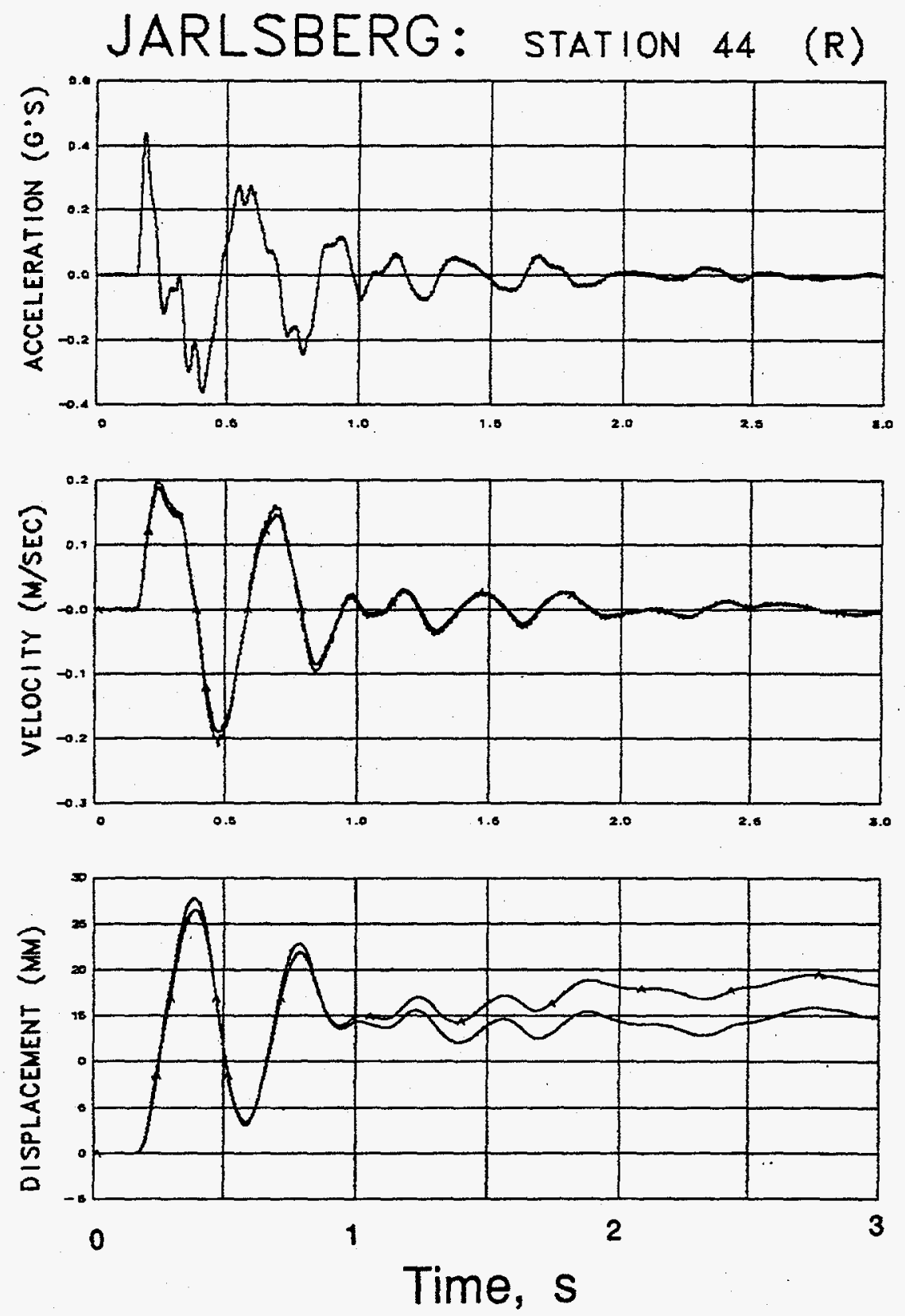

Figure 5.5 Explosion-induced radial-horizontal motion at a depth of $304 \mathrm{~m}$ in hole Ue10aa (station 44). Traces annotated with "A" were derived from the accelerometer. 

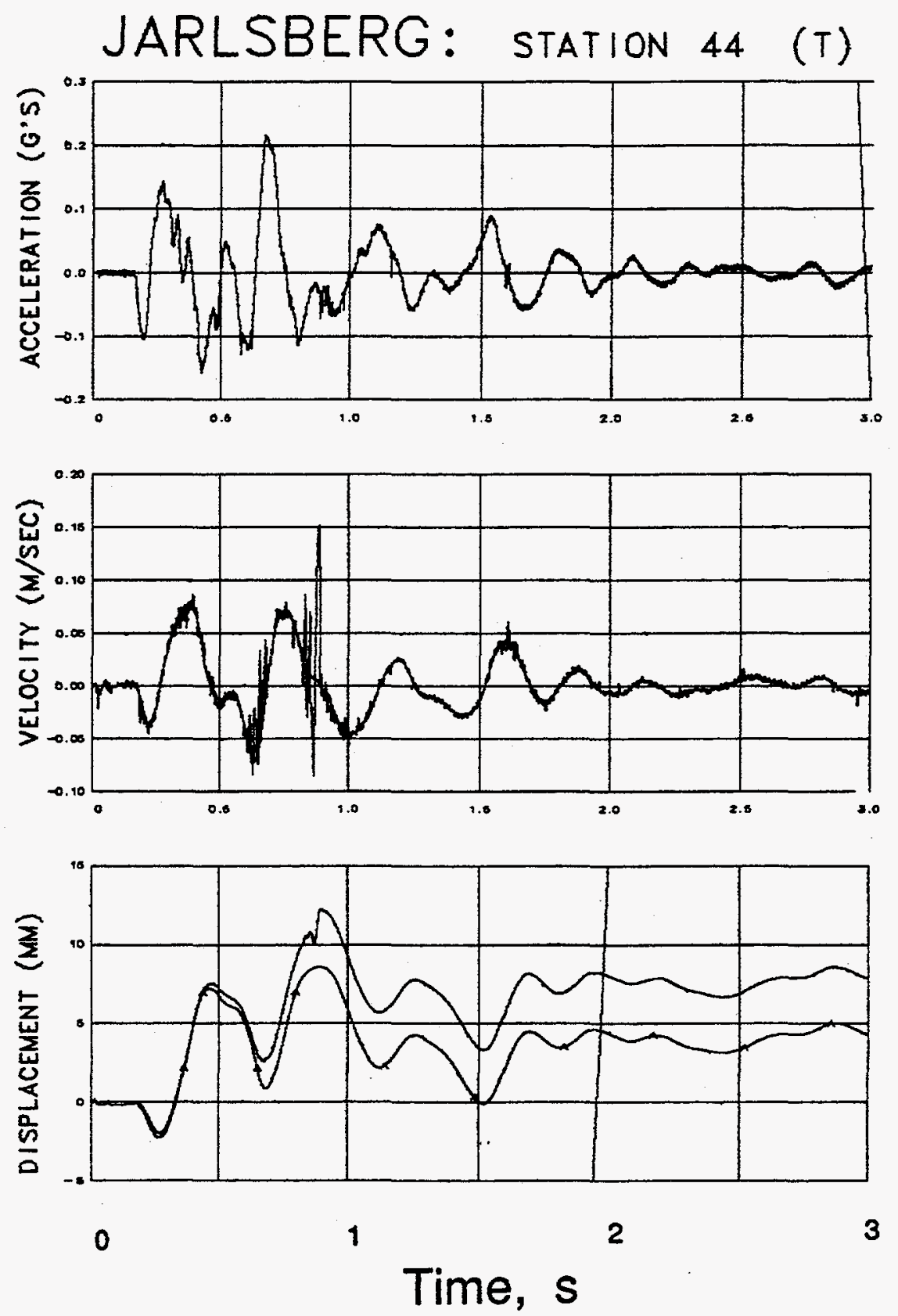

Figure 5.6 Explosion-induced transverse-horizontal motion at a depth of $304 \mathrm{~m}$ in hole Ue10aa (station 44). Traces annotated with "A" were derived from the accelerometer. 

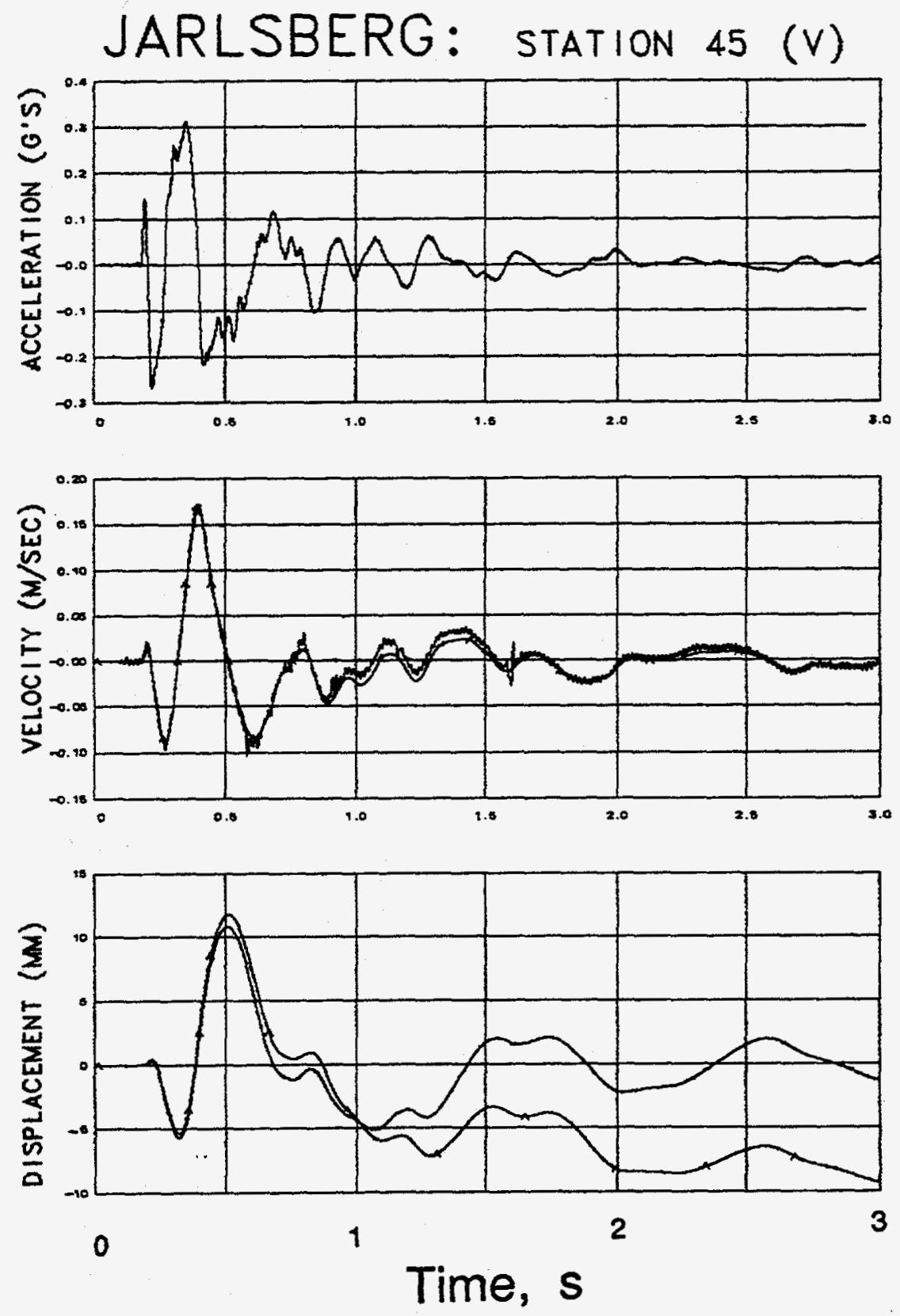

Figure 5.7 Explosion-induced vertical motion at a depth of $251 \mathrm{~m}$ in hole Ue10aa (station 45). Traces annotated with " $A$ " were derived from the accelerometer. 

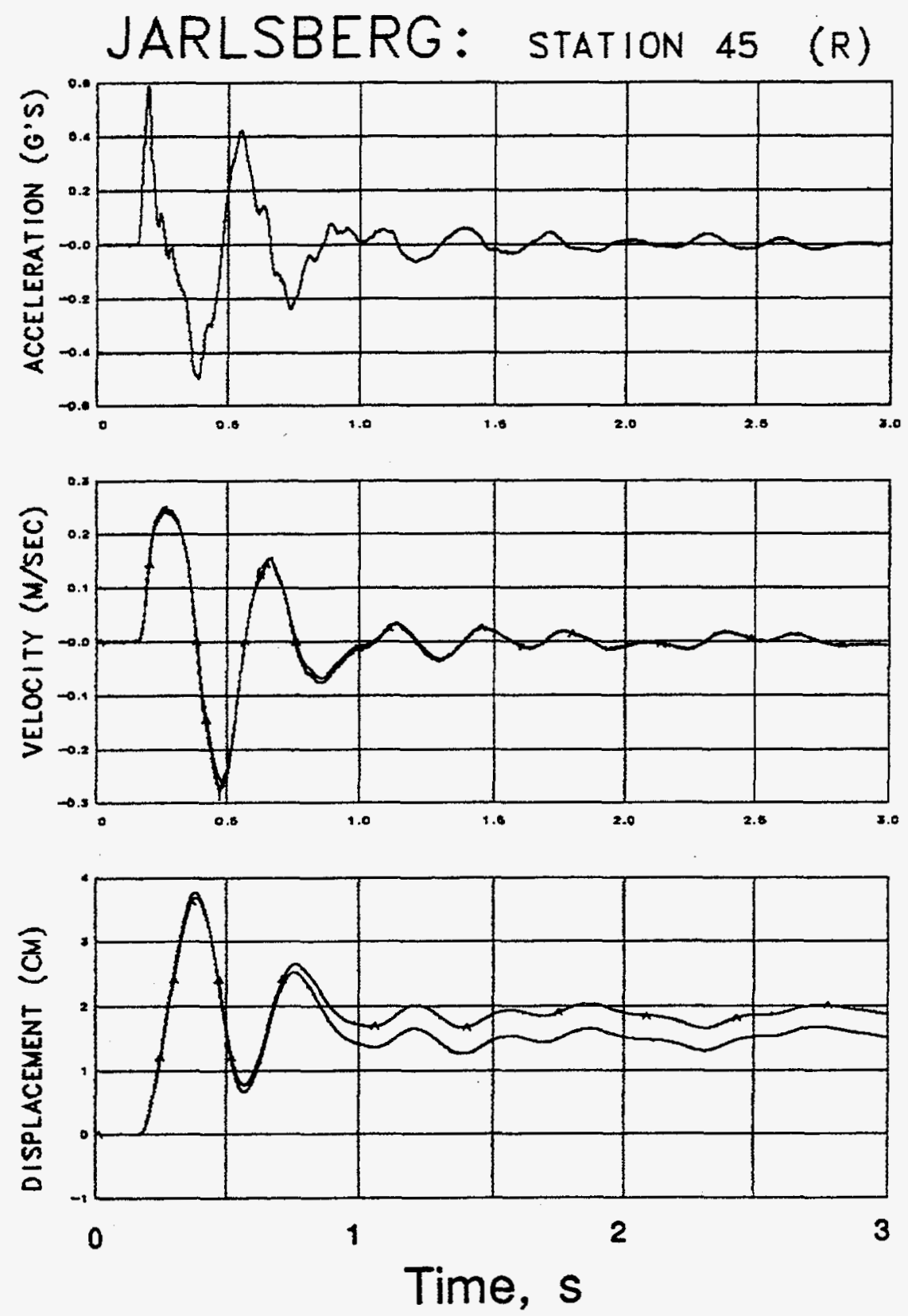

Figure 5.8 Explosion-induced radial-horizontal motion at a depth of $251 \mathrm{~m}$ in hole Ue10aa (station 45). Traces annotated with " $\mathrm{A}$ " were derived from the accelerometer. 

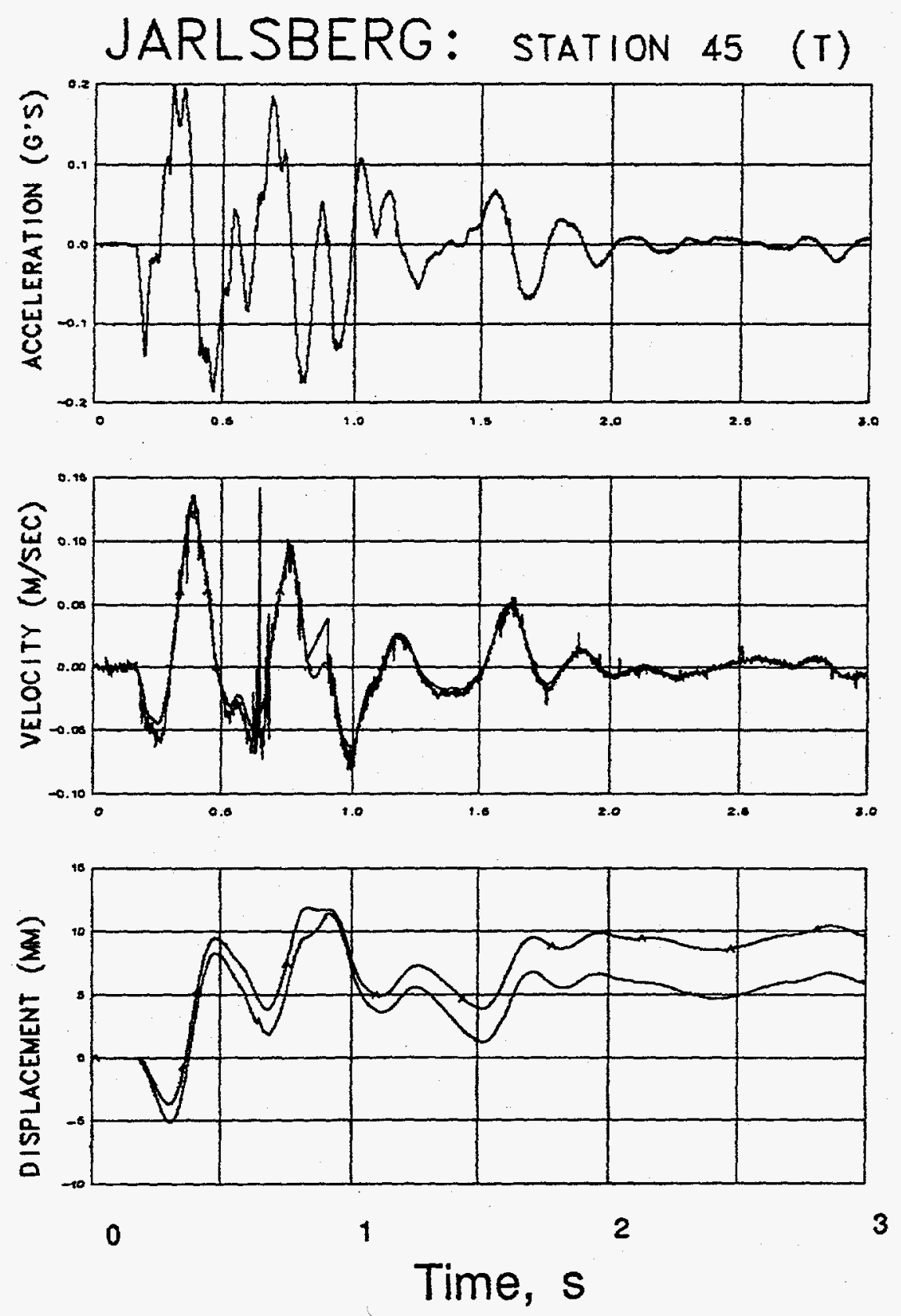

Figure 5.9 Explosion-induced transverse-horizontal motion at a depth of $251 \mathrm{~m}$ in hole Ue10aa (station 45). Traces annotated with " $A$ " were derived from the accelerometer. 


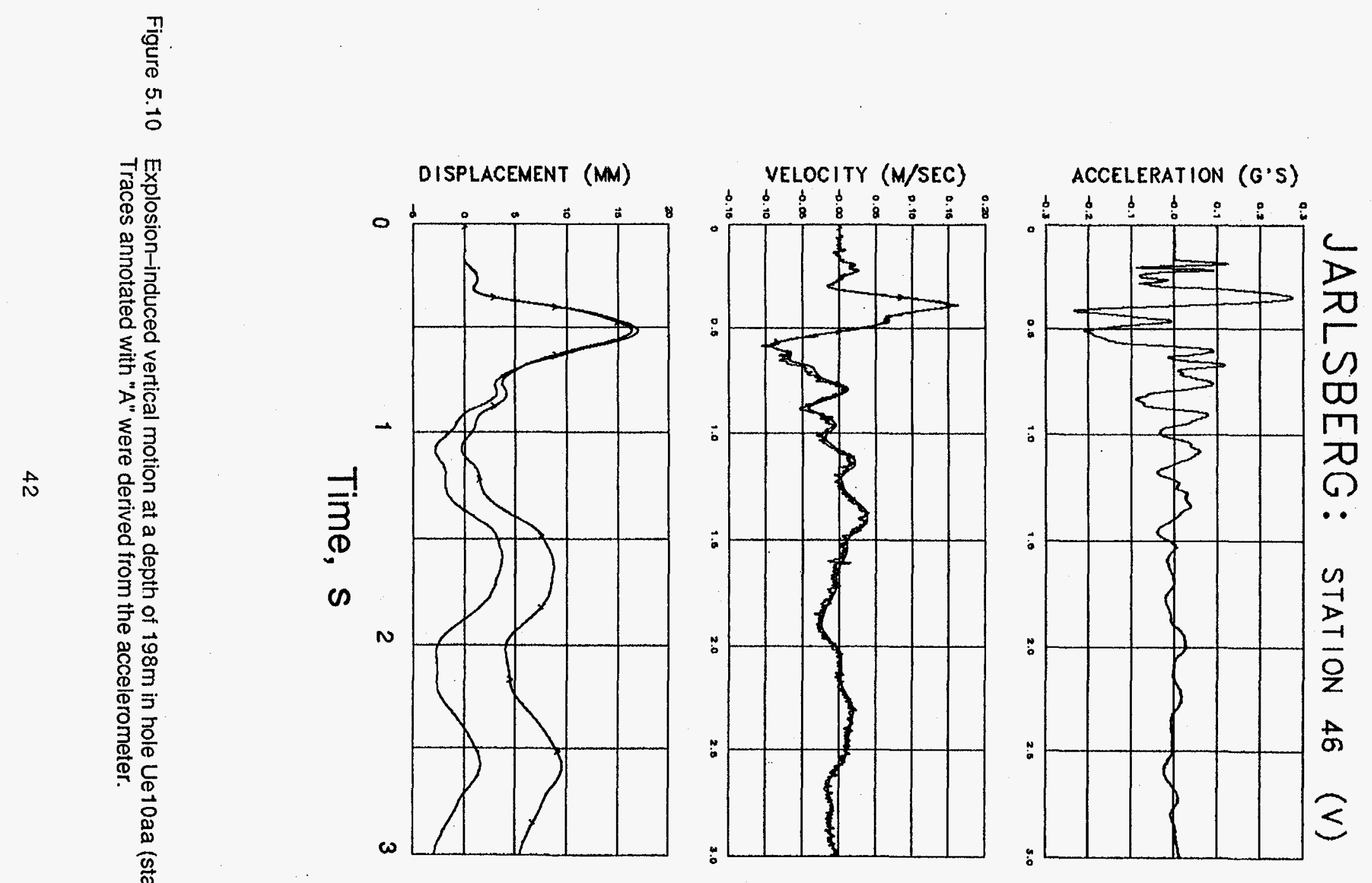



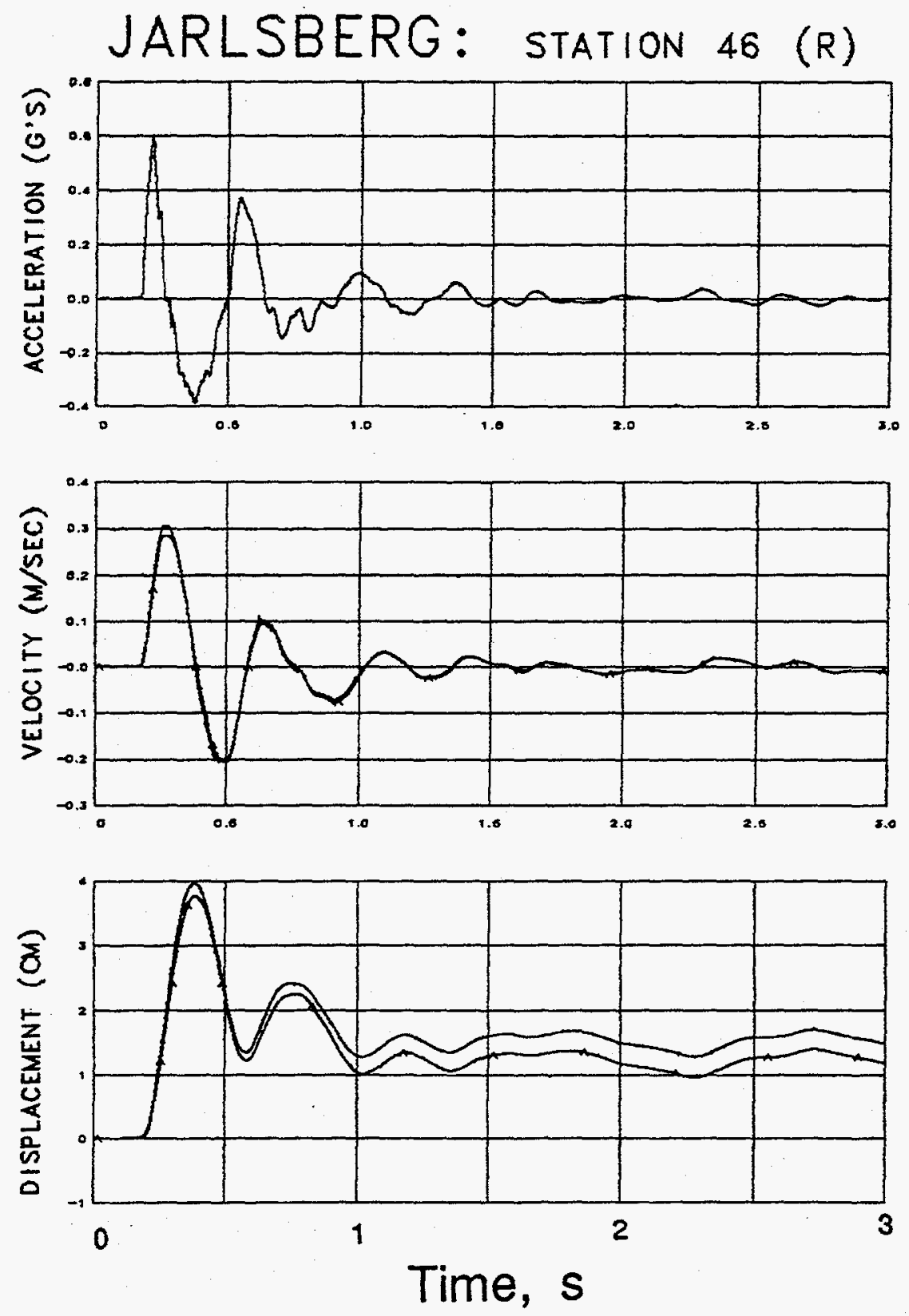

Figure 5.11 Explosion-induced radial-horizontal motion at a depth of $198 \mathrm{~m}$ in hole Ue10aa (station 46). Traces annotated with "A" were derived from the accelerometer. 

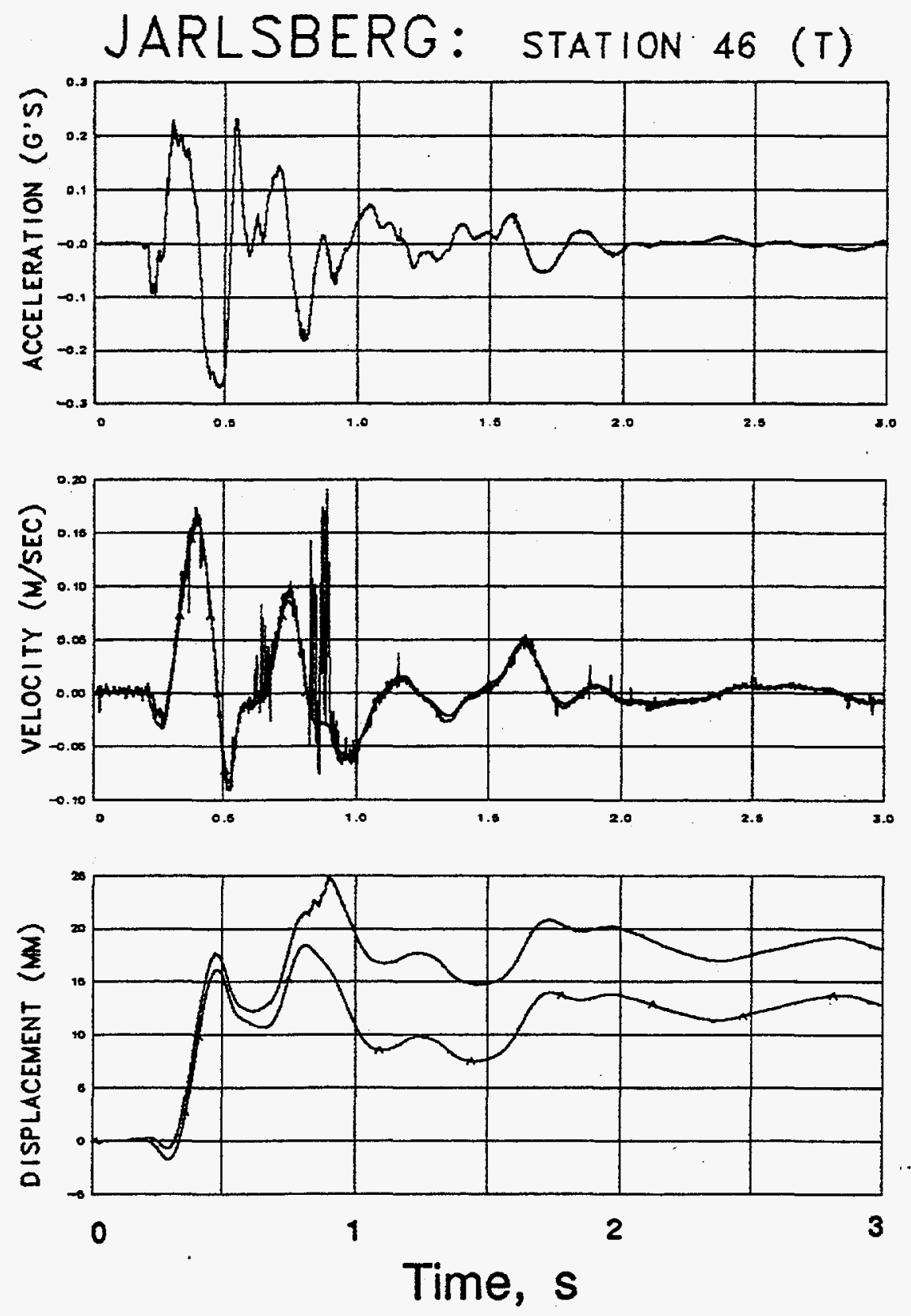

Figure 5.12 Explosion-induced transverse-horizontal motion at a depth of $198 \mathrm{~m}$ in hole Ue 10aa (station 46). Traces annotated with "A" were derived from the accelerometer. 

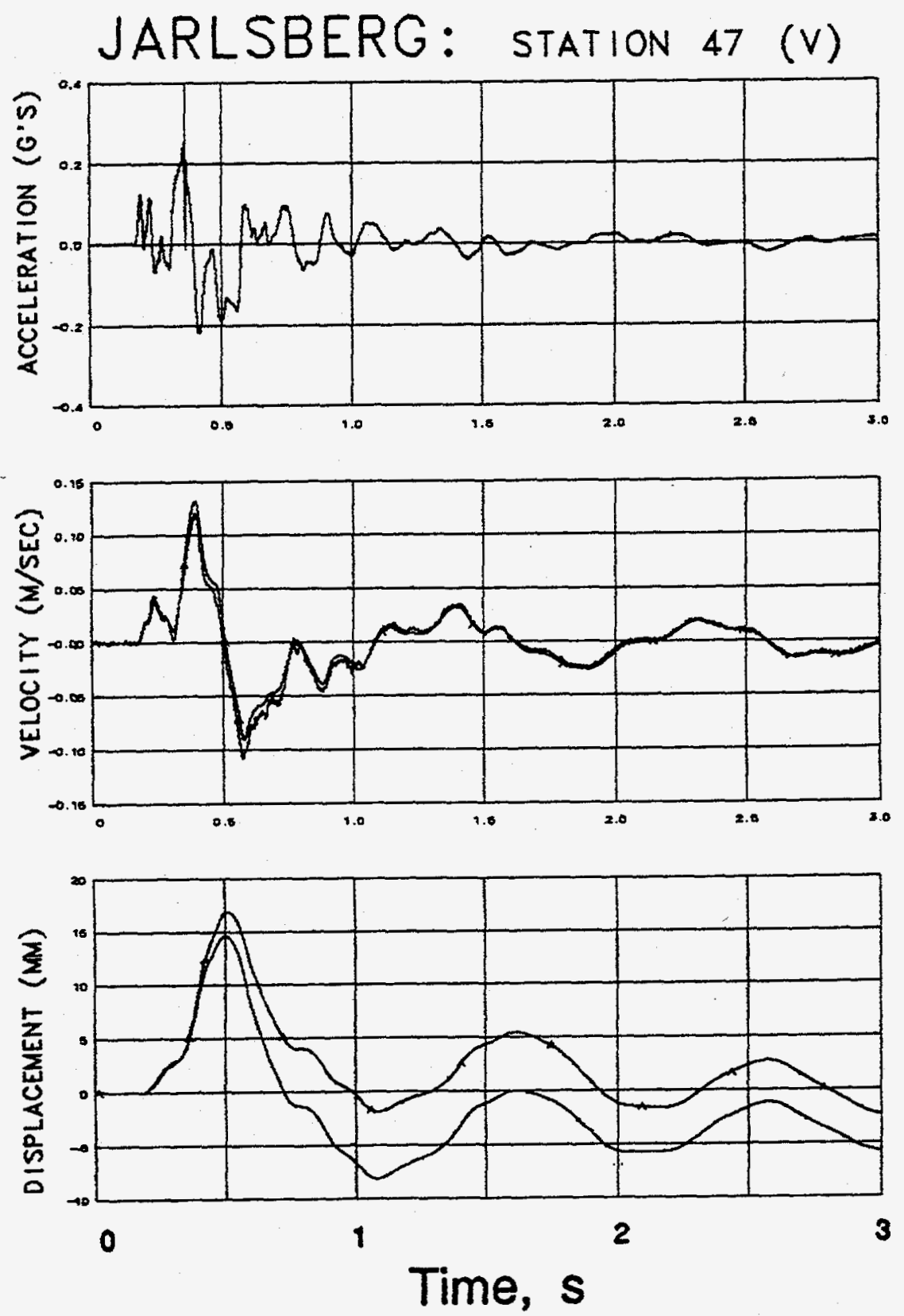

Figure 5.13 Explosion-induced vertical motion at a depth of $173 \mathrm{~m}$ in hole Ue 10 aa (station 47 ). Traces annotated with " $\mathrm{A}$ " were derived from the accelerometer. 

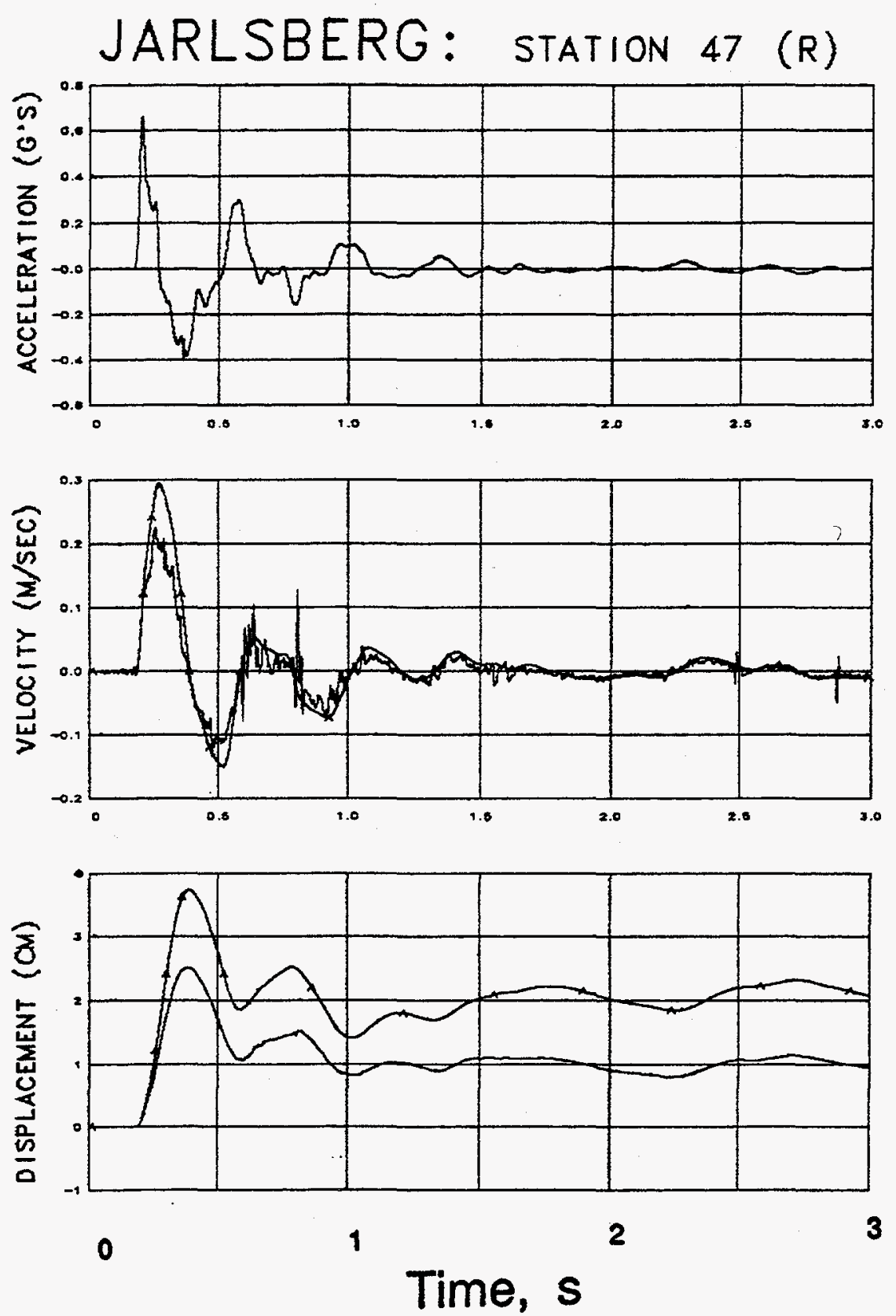

Figure 5.14 Explosion-induced radial-horizontal motion at a depth of $173 \mathrm{~m}$ in hole Ue10aa (station 47). Traces annotated with "A" were derived from the accelerometer. 

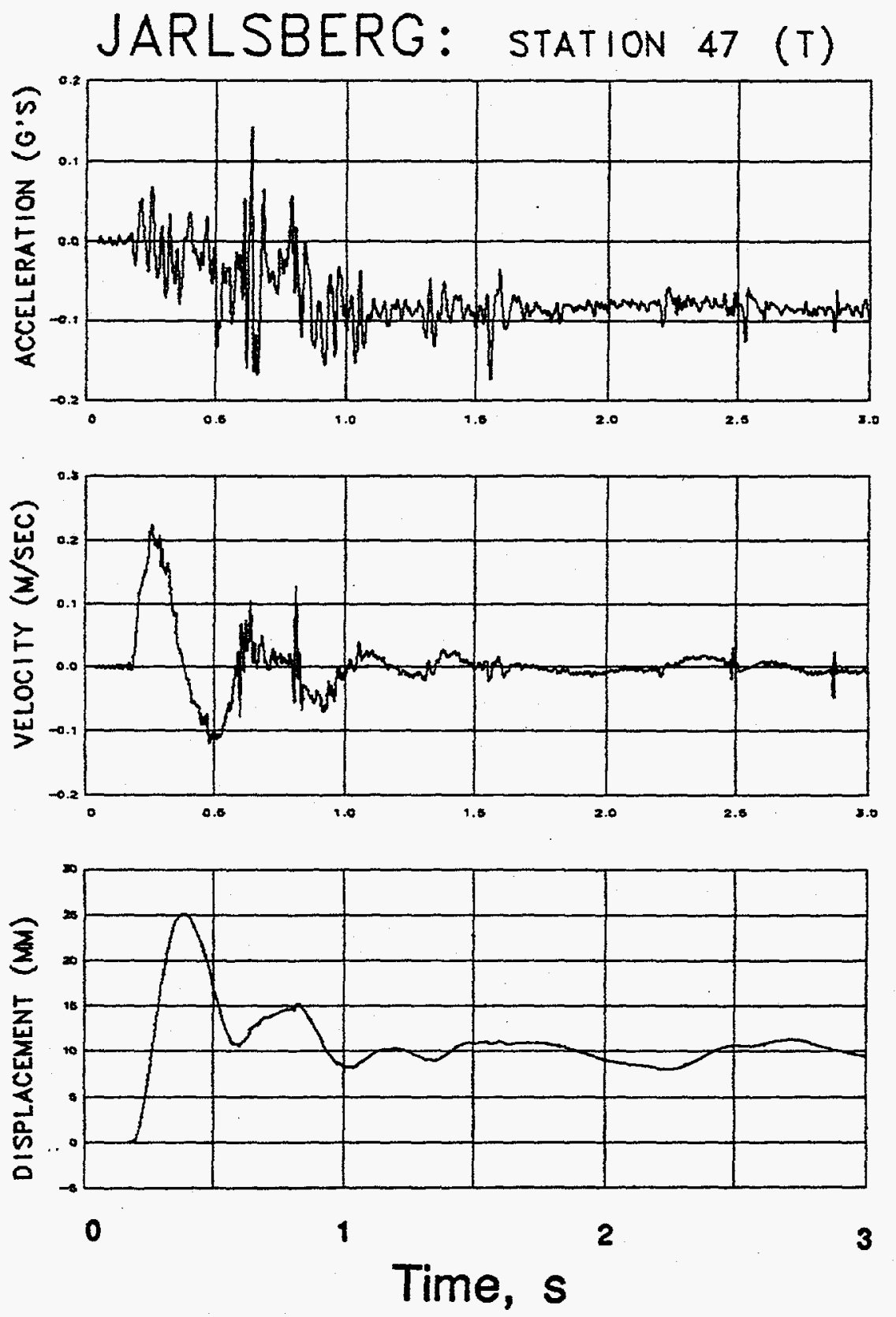

Figure 5.15 Explosion-induced transverse-horizontal motion at a depth of $173 \mathrm{~m}$ in hole Ue10aa (station 47). Traces annotated with " $A$ " were derived from the accelerometer. 


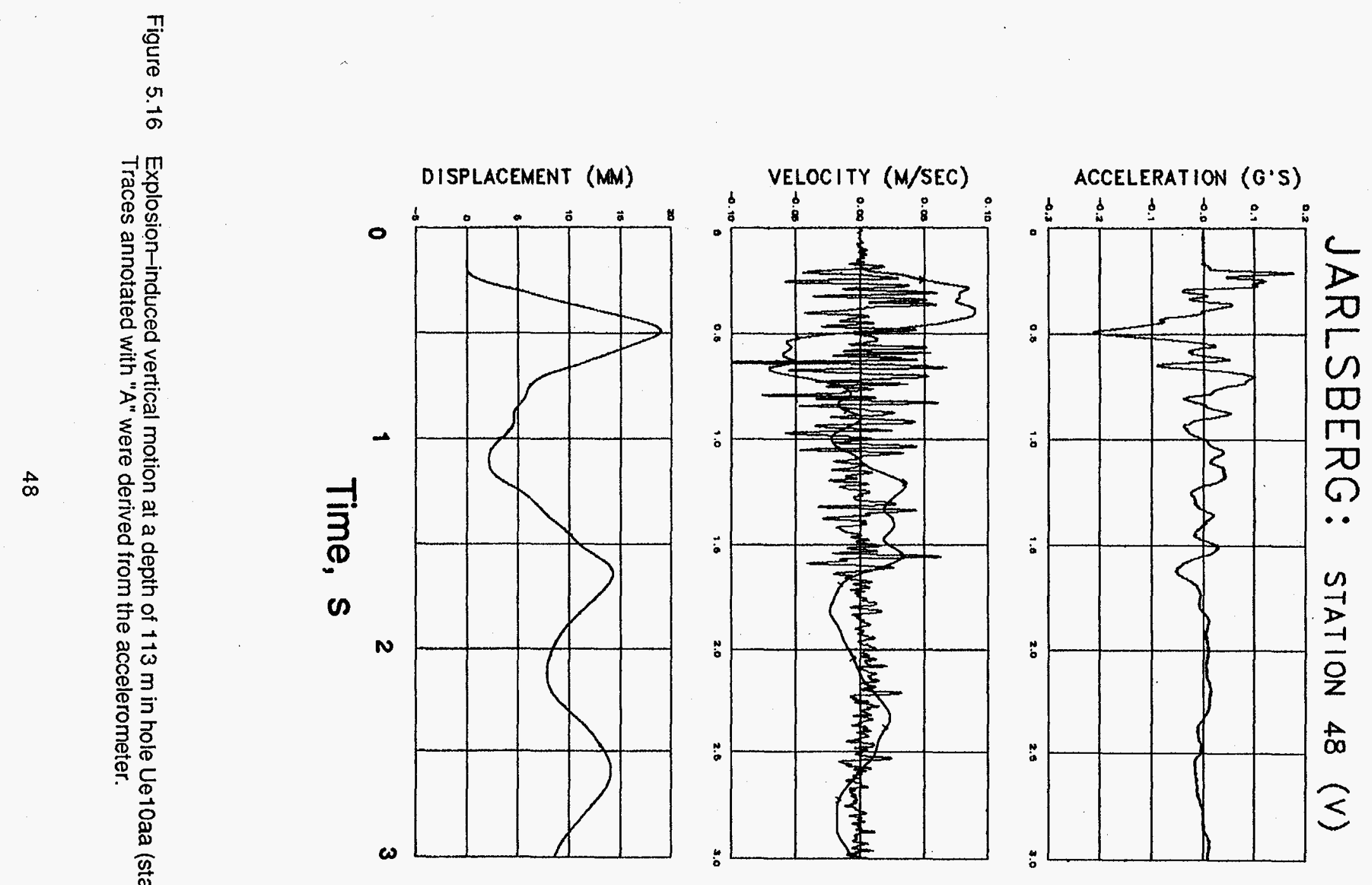



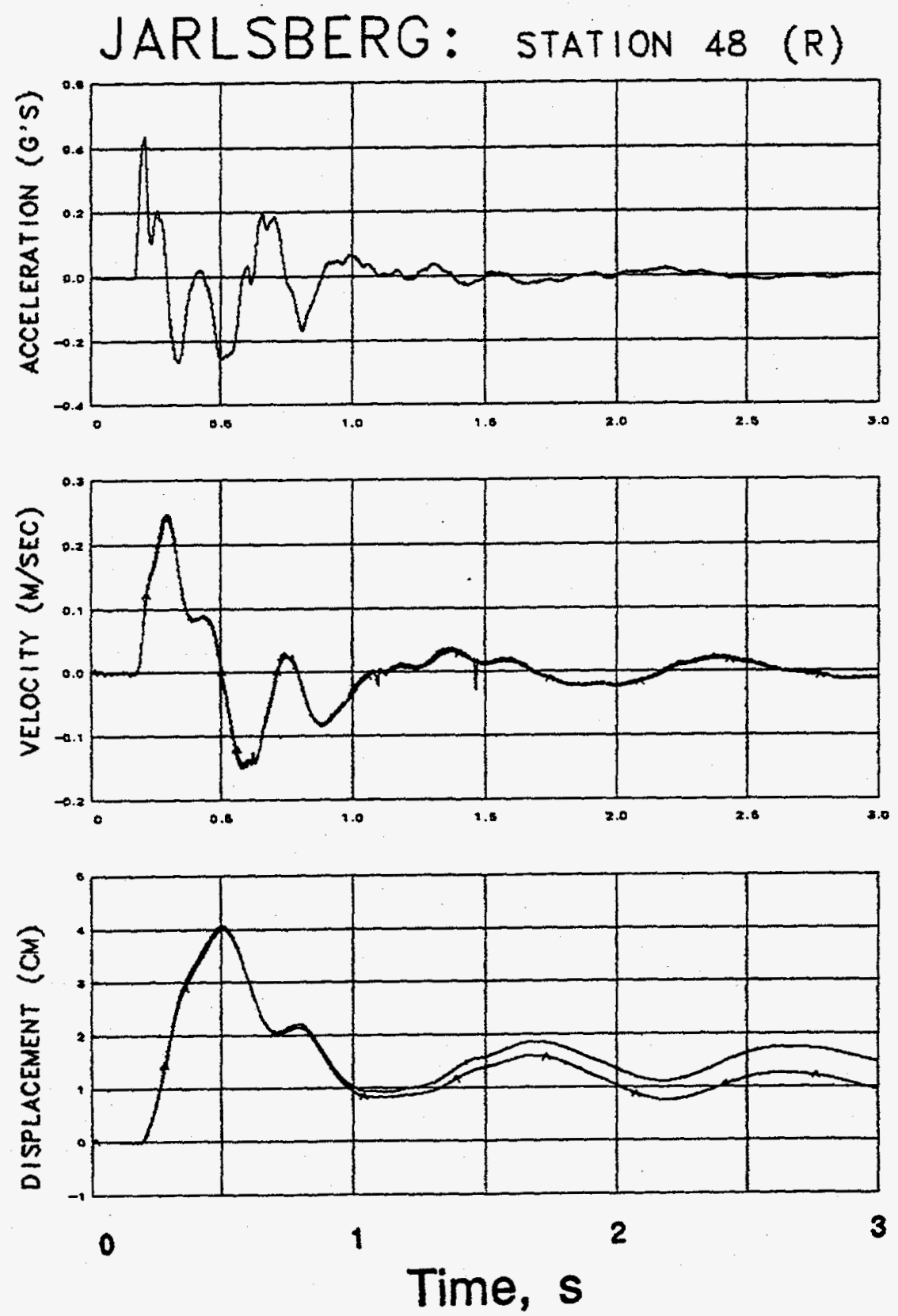

Figure 5.17 Explosion-induced radial-horizontal motion at a depth of $113 \mathrm{~m}$ in hole Ue10aa (station 48). Traces annotated with "A" were derived from the accelerometer. 

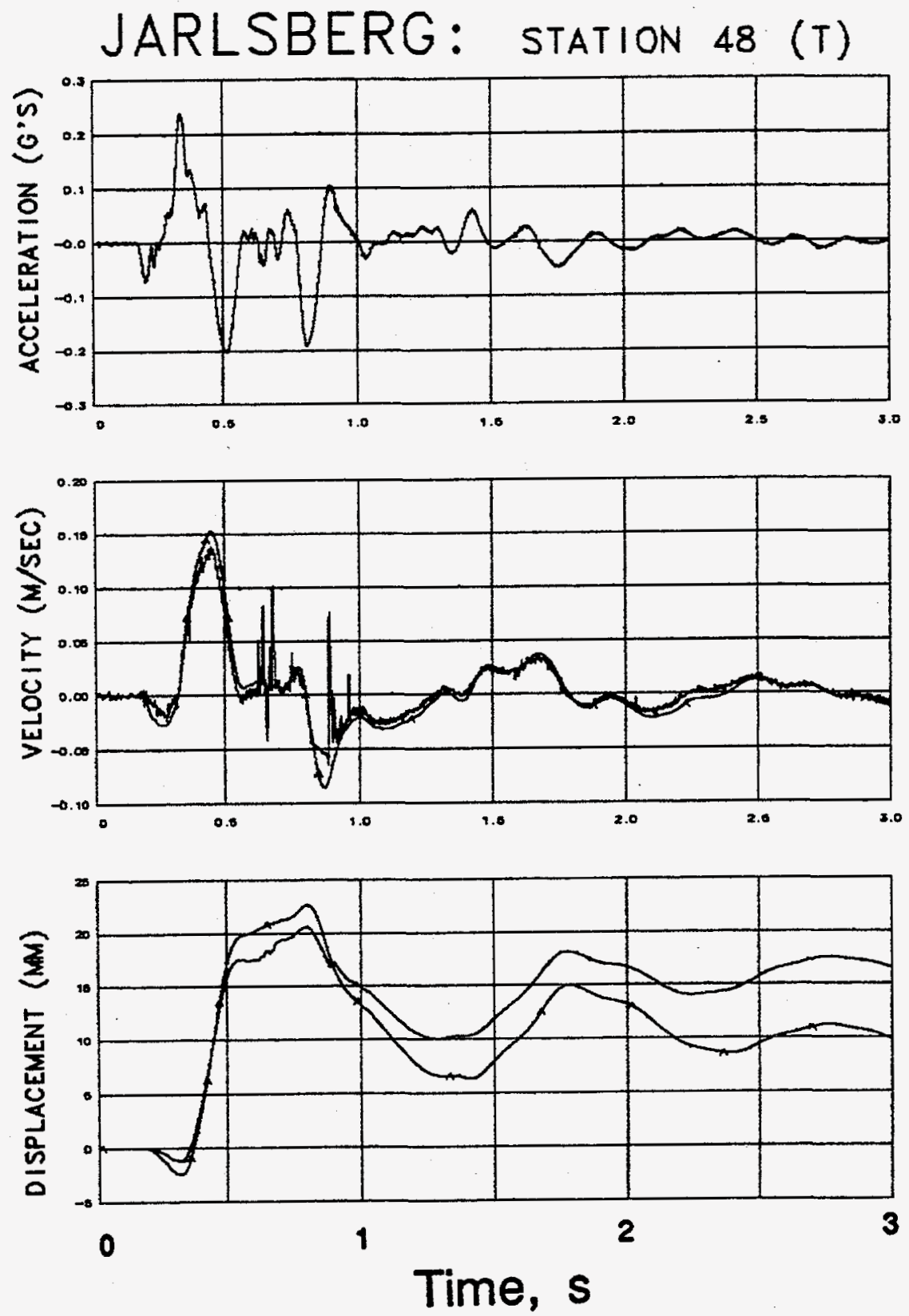

Figure 5.18 Explosion-induced transverse-horizontal motion at a depth of $113 \mathrm{~m}$ in hole Ue10aa (station 48). Traces annotated with "A" were derived from the accelerometer. 

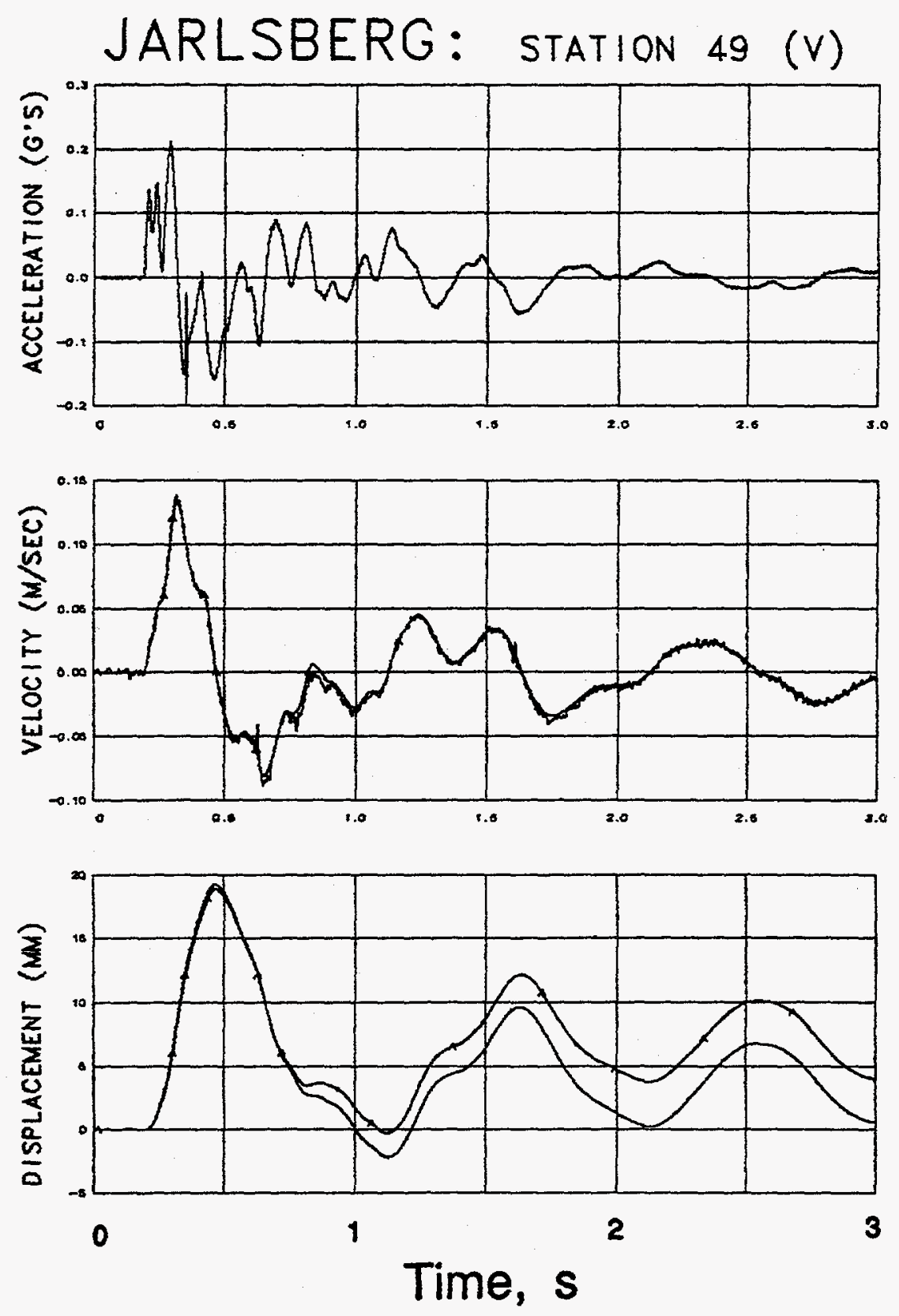

Figure 5.19 Explosion-induced vertical motion at a depth of $56 \mathrm{~m}$ in hole Ue10aa (station 49). Traces annotated with " $A$ " were derived from the accelerometer. 

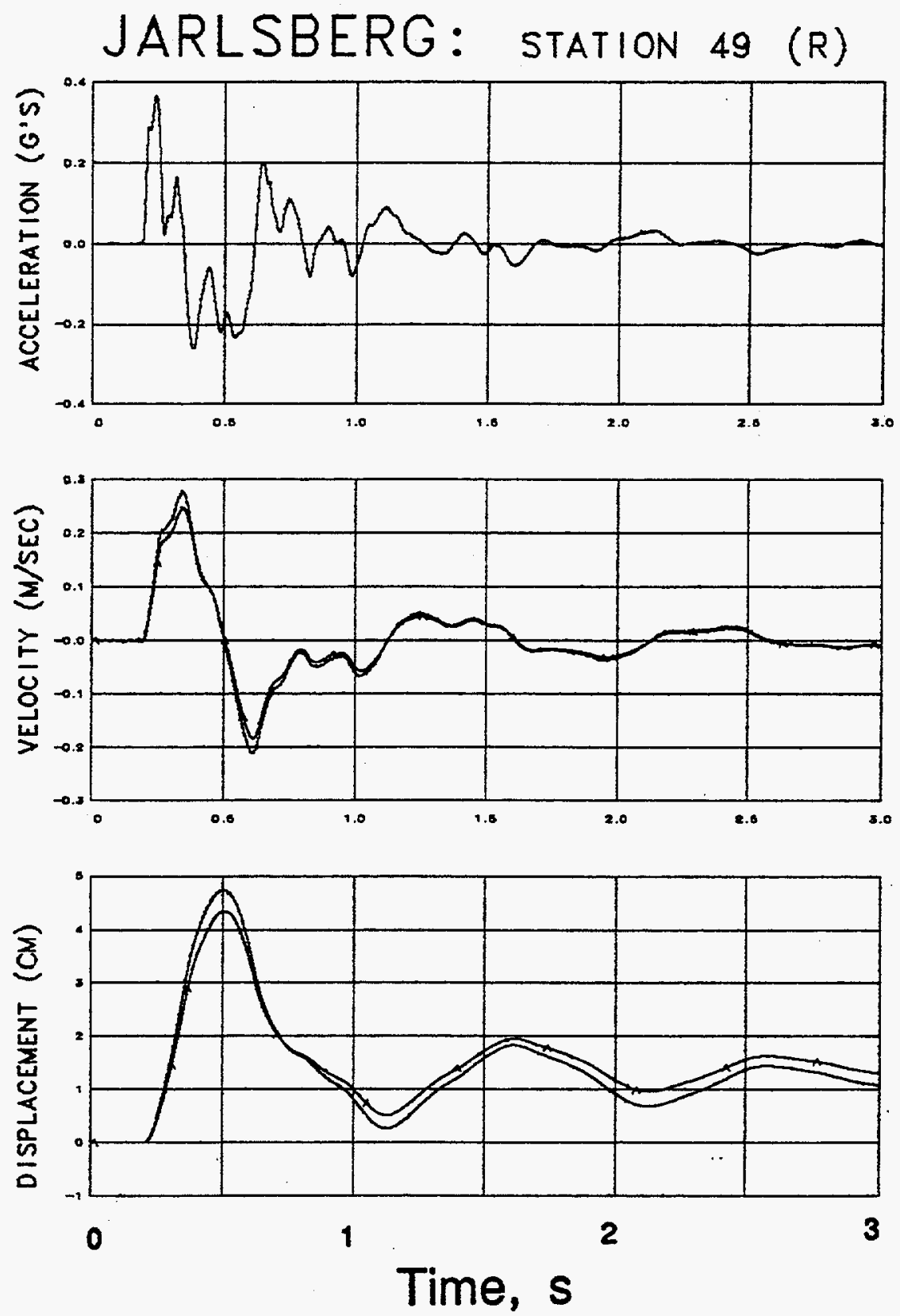

Figure 5.20 Explosion-induced radial-horizontal motion at a depth of $56 \mathrm{~m}$ in hole Ue10aa (station 49). Traces annotated with " $A$ " were derived from the accelerometer. 

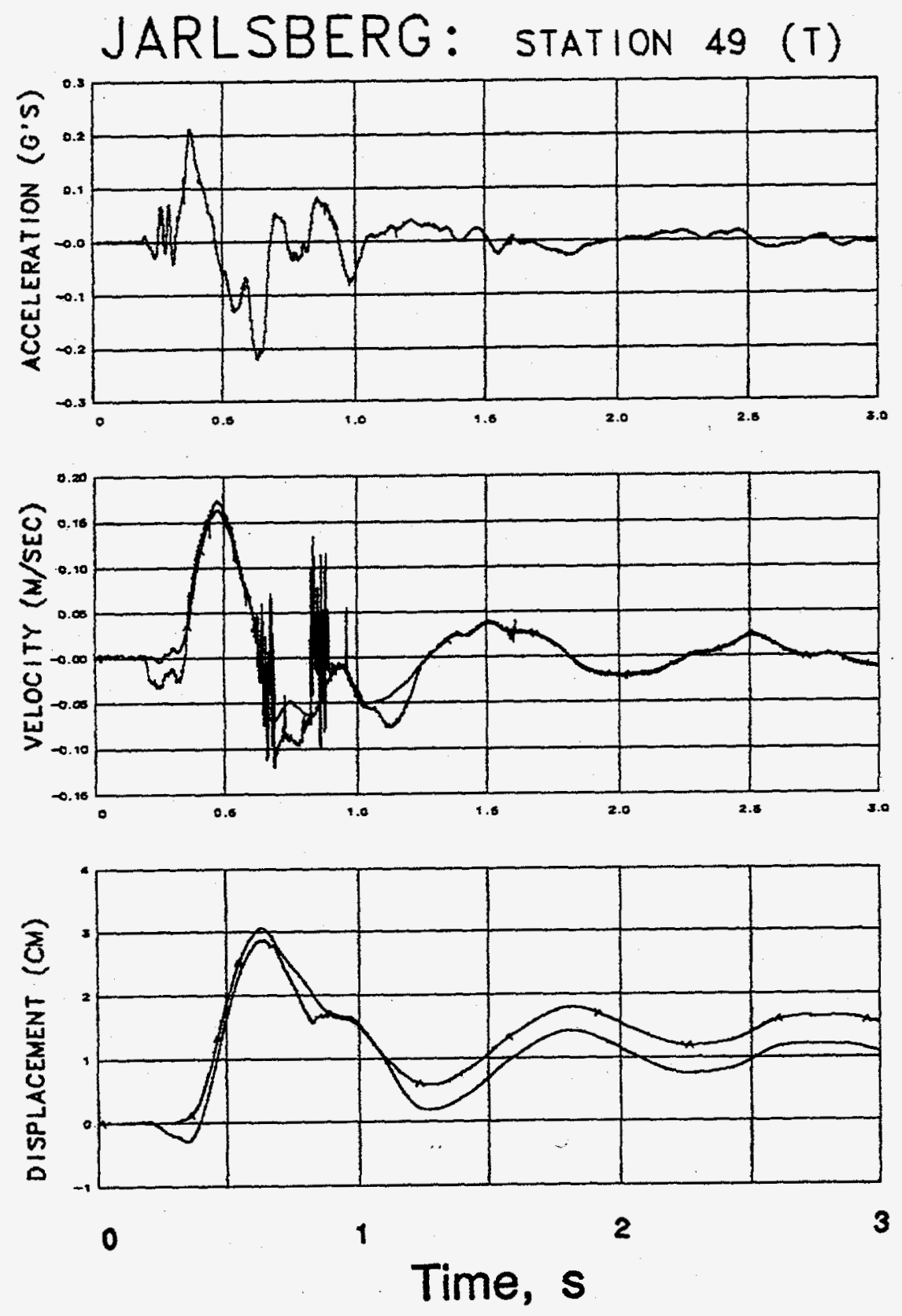

Figure 5.21 Explosion-induced transverse-horizontal motion at a depth of $56 \mathrm{~m}$ in hole Ue10aa (station 49). Traces annotated with " $A$ " were derived from the accelerometer. 


\section{JARLSBERG}
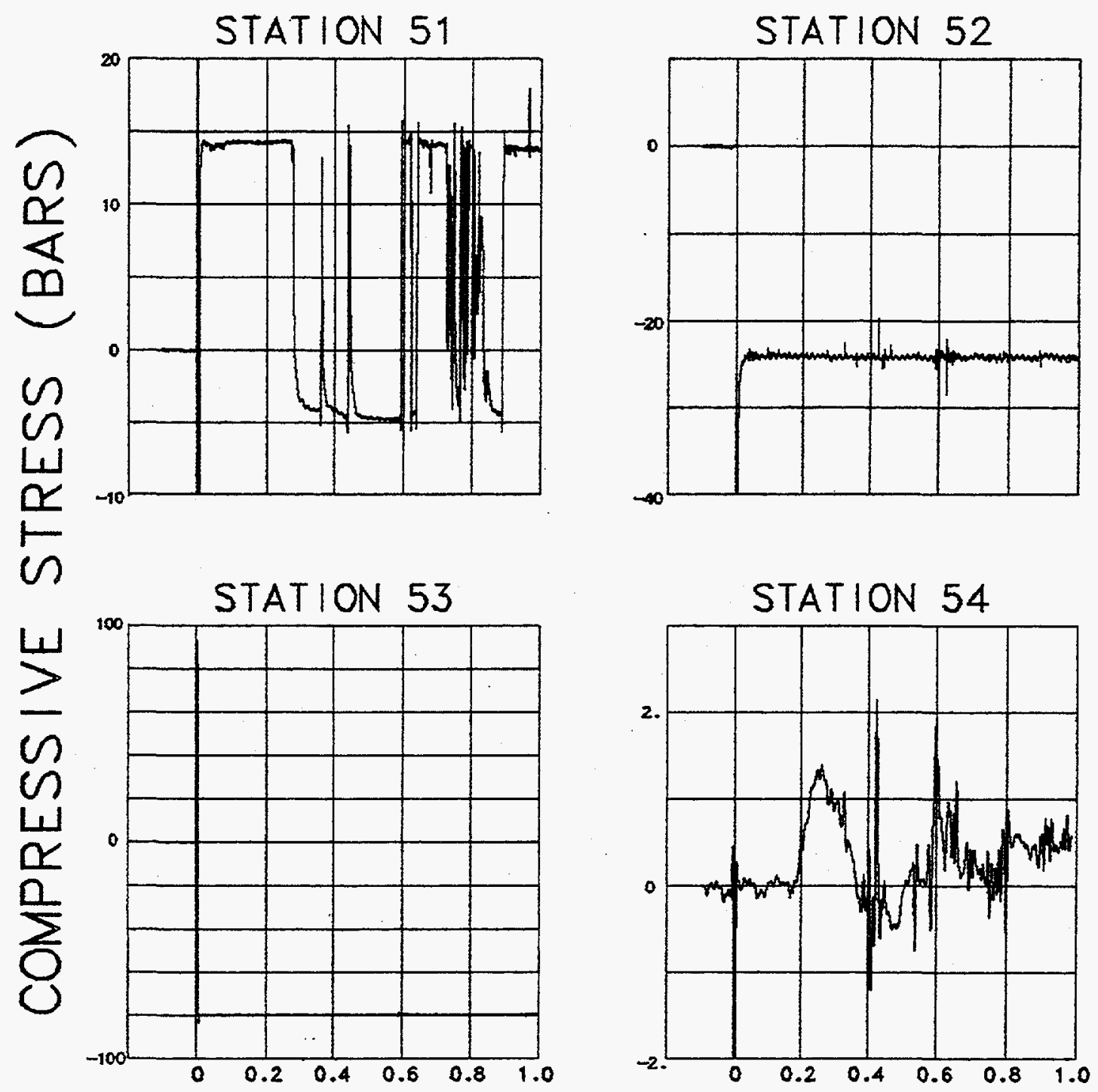

Figure 5.22. Mean stress (pressure) measured in hole Ue10aa. It is suggested that only station 54 reported valid information. Stations 55 and 56 were inoperative pre-shot and not recorded. 


\section{Table 5.1}

\section{Satellite Hole (free-field) Motion Summary}

\begin{tabular}{|c|c|c|c|c|c|c|}
\hline Gauge & $\begin{array}{c}\text { Slant } \\
\text { Range } \\
\text { (m) }\end{array}$ & $\begin{array}{l}\text { Arrival } \\
\text { Time } \\
\text { (ms) }\end{array}$ & $\begin{array}{c}\text { Peak } \\
\text { Acceleration } \\
\text { (g) }\end{array}$ & $\begin{array}{c}\text { Peak } \\
\text { Velocity } \\
(\mathrm{m} / \mathrm{s})\end{array}$ & $\begin{array}{c}\text { Peak } \\
\text { Displacement } \\
\text { (m) }\end{array}$ & $\begin{array}{c}\text { Residual } \\
\text { Displacement } \\
(\mathrm{mm})\end{array}$ \\
\hline $41 \mathrm{av}$ & & 138 & 0.24 & 0.99 & 0.006 & 10 \\
\hline 41 uv & \multirow{3}{*}{$\begin{array}{c}\text { (a) } \\
361.0\end{array}$} & & & & & \\
\hline $41 a r$ & & 136 & 0.146 & 0.042 & 0.0075 & 3 \\
\hline 41ur & & & \multirow{3}{*}{0.048} & 0.112 & 0.014 & 2 \\
\hline 41at & \multirow[t]{2}{*}{ (b) } & \multirow[t]{2}{*}{141} & & 0.100 & 0.0032 & -8 \\
\hline 41ut & & & & -0.056 & -0.0062 & 1 \\
\hline $44 a v$ & \multirow{6}{*}{327.4} & \multirow[t]{2}{*}{156} & \multirow[t]{2}{*}{-0.28} & -0.110 & -0.0083 & -9 \\
\hline 44uv & & & & -0.110 & -0.0083 & 0 \\
\hline $44 a r$ & & \multirow[t]{2}{*}{159} & \multirow[t]{2}{*}{0.44} & 0.187 & 0.0264 & 17 \\
\hline 44ur & & & & 0.196 & 0.0277 & 14 \\
\hline 44at & & \multirow[t]{2}{*}{158} & \multirow[t]{2}{*}{-0.103} & -0.037 & -0.0022 & 4 \\
\hline 44ut & & & & -0.037 & -0.0022 & 7 \\
\hline $45 a v$ & \multirow{6}{*}{314.7} & \multirow{2}{*}{156} & \multirow{2}{*}{-0.27} & -0.092 & -0.0054 & -7 \\
\hline $45 u v$ & & & & -0.096 & -0.0052 & 2 \\
\hline $45 \mathrm{ar}$ & & \multirow[t]{2}{*}{152} & \multirow[t]{2}{*}{0.59} & 0.240 & 0.0367 & 18 \\
\hline $45 u r$ & & & & -0.250 & 0.0375 & 15 \\
\hline 45 at & & \multirow[t]{2}{*}{154} & \multirow[t]{2}{*}{-0.14} & -0.045 & -0.0037 & 8 \\
\hline 45ut & & & & -0.058 & -0.0050 & 6 \\
\hline $46 a v$ & \multirow{6}{*}{310.5} & \multirow[t]{2}{*}{162} & \multirow[t]{2}{*}{0.125} & 0.021 & 0.0164 & 7 \\
\hline $46 u v$ & & & & 0.022 & 0.0172 & 3 \\
\hline $46 a r$ & & \multirow[t]{2}{*}{166} & \multirow[t]{2}{*}{0.600} & 0.280 & 0.0375 & 12 \\
\hline $46 u r$ & & & & 0.310 & 0.0396 & 15 \\
\hline $46 a t$ & & \multirow[t]{2}{*}{166} & \multirow[t]{2}{*}{-0.095} & -0.033 & -0.0018 & 12 \\
\hline 46ut & & & & -0.025 & -0.0010 & 17 \\
\hline $47 a v$ & \multirow{6}{*}{$\begin{array}{l}3+2.2 \\
\text { (a) }\end{array}$} & 168 & 0.123 & 0.038 & 0.0013 & 0 \\
\hline $47 u v$ & & & & 0.044 & 0.00145 & -3 \\
\hline $47 a r$ & & 168 & 0.660 & 0.294 & 0.0372 & 20 \\
\hline 47ur & & & & 0.320 & 0.0395 & 15 \\
\hline 47at & & & & & & \\
\hline 47ut & & 180 & & -0.050 & -0.0032 & 8 \\
\hline $\begin{array}{l}48 a v \\
48 u y\end{array}$ & (a) & 168 & 0.175 & 0.084 & 0.0189 & 10 \\
\hline $48 a r$ & 328.0 & 166 & 0.430 & 0.244 & 0.0400 & 10 \\
\hline $48 u r$ & & & & 0.248 & 0.0405 & 15 \\
\hline $\begin{array}{l}\text { 48at } \\
\text { 48ut }\end{array}$ & & 166 & -0.071 & $\begin{array}{l}-0.028 \\
-0.022\end{array}$ & $\begin{array}{r}-0.0025 \\
-0.0011\end{array}$ & $\begin{array}{c}7 \\
17(c)\end{array}$ \\
\hline 49av & & 185 & 0.135 & 0.133 & 0.0188 & 6 \\
\hline $49 u v$ & & & & 0.137 & 0.0187 & 5 \\
\hline $49 a r$ & 342.8 & 185 & 0.365 & 0.248 & 0.0433 & 13 \\
\hline $49 u r$ & & & & 0.277 & 0.0470 & 11 \\
\hline $\begin{array}{l}\text { 49at } \\
49 u t\end{array}$ & & 184 & -0.033 & $\begin{array}{l}0.160 \\
\text { (c) }\end{array}$ & 0.0305 & 15 \\
\hline
\end{tabular}

(a) Malfunction.

(b) These data are highly questionable.

(c) Data invalid: noise influences magnitude 


\section{Table 5.2}

Satellite Hole Accelerometer Characteristics ${ }^{\dagger}$

\begin{tabular}{|c|c|c|c|}
\hline Gauge & $\begin{array}{c}\text { Natural } \\
\text { Frequency } \\
(\mathrm{Hz})\end{array}$ & $\begin{array}{l}\text { Damping } \\
\text { Ratio }\end{array}$ & $\begin{array}{c}\text { System } \\
\text { Range } \\
\text { (g) }\end{array}$ \\
\hline $41 a v$ & 182 & 0.70 & 1.6 \\
\hline $41 a r$ & 138 & 0.65 & 1.6 \\
\hline 41at & 175 & 0.70 & 2.0 \\
\hline $44 a v$ & 180 & 0.70 & 2.0 \\
\hline 44ar & 122 & 0.75 & 2.0 \\
\hline 44at & 158 & 0.85 & 2.0 \\
\hline $45 a v$ & 170 & 0.65 & 2.0 \\
\hline $45 a r$ & 117 & 0.65 & 2.0 \\
\hline 45at & 132 & 0.65 & 2.0 \\
\hline $46 a v$ & 175 & 0.70 & 2.0 \\
\hline $46 a r$ & 170 & 0.65 & 2.0 \\
\hline 46at & 145 & 0.70 & 2.0 \\
\hline $47 a v$ & 175 & 0.60 & 2.0 \\
\hline $47 a r$ & 175 & 0.75 & 2.0 \\
\hline 47 at & 145 & 0.65 & 2.0 \\
\hline $48 a v$ & 184 & 0.65 & 2.0 \\
\hline $48 a r$ & 169 & 0.70 & 2.0 \\
\hline 48at & 145 & 0.75 & 2.0 \\
\hline $49 a v$ & 170 & 0.65 & 2.0 \\
\hline $49 a r$ & 120 & 0.65 & 2.0 \\
\hline 49at & 152 & 0.60 & 2.0 \\
\hline
\end{tabular}

$\dagger_{\text {All accelerometers are variable reluctance devices }}$ 


\section{Table 5.3}

\section{Satellite Hole Velocimeter Characteristics}

\begin{tabular}{|c|c|c|c|c|c|}
\hline Gauge & $\begin{array}{c}\text { Natural } \\
\text { Frequency } \\
(\mathrm{Hz})\end{array}$ & $\begin{array}{c}\text { Time to } 0.5 \\
\text { Amplitude } \\
\text { (s) }\end{array}$ & $\begin{array}{c}\text { Calibration } \\
\text { Temperature } \\
\left({ }^{\circ} \mathrm{C}\right) \\
\end{array}$ & $\begin{array}{c}\text { Operate } \\
\text { Temperature } \\
\left({ }^{\circ} \mathrm{C}\right) \\
\end{array}$ & $\begin{array}{c}\text { System } \\
\text { Range } \\
(\mathrm{m} / \mathrm{s})\end{array}$ \\
\hline 41uv & 3.566 & 8.89 & 23.899 & 29.91 & 1.4 \\
\hline $41 u r$ & 3.600 & 9.39 & 24.17 & 29.91 & 1.4 \\
\hline 41ut & 3.594 & 9.38 & 24.07 & 29.91 & 1.4 \\
\hline $44 u v$ & 3.543 & 8.82 & 25.80 & 28.93 & 2.0 \\
\hline 44ur & 3.518 & 9.94 & 22.54 & 28.93 & 2.0 \\
\hline 44ut & 3.556 & 9.17 & 24.08 & 28.93 & 2.0 \\
\hline $45 u v$ & 3.657 & 8.61 & 25.90 & 27.05 & 2.0 \\
\hline $45 u r$ & 3.502 & 9.38 & 24.24 & 27.05 & 2.0 \\
\hline $45 u t$ & 3.384 & 9.28 & 24.55 & 27.05 & 2.0 \\
\hline $46 u v$ & 3.518 & 9.74 & 26.05 & 23.61 & 2.0 \\
\hline 46ur & 3.444 & 9.30 & 24.34 & 23.61 & 2.0 \\
\hline 46ut & 3.624 & 9.50 & 22.73 & 23.61 & 2.0 \\
\hline $47 u v$ & 3.551 & 9.22 & 25.46 & 22.89 & 2.0 \\
\hline $47 u r$ & 3.685 & 9.36 & 22.82 & 22.89 & 2.0 \\
\hline 47ut & 3.577 & 9.20 & 23.06 & 22.89 & 2.0 \\
\hline $48 u v$ & 3.640 & 8.38 & 25.63 & 18.83 & 2.0 \\
\hline $48 u r$ & 3.452 & 8.82 & 24.46 & 18.83 & 2.0 \\
\hline 48ut & 3.362 & 9.76 & 22.77 & 18.83 & 2.0 \\
\hline 49uv & 3.396 & 10.32 & 25.72 & 17.73 & 2.0 \\
\hline $49 u r$ & 3.512 & 9.21 & 22.39 & 17.73 & 2.0 \\
\hline 49ut & 3.464 & 9.27 & 22.40 & 17.73 & 2.0 \\
\hline
\end{tabular}


(1) JL. Wagoner and S. R. Clark, "U10ca, $210 \mathrm{~m}$, Preliminary Site Characteristics Summary", CP 83-28, Lawrence Livermore National Laboratory, CA, April 15, 1983.

(2) William G. Webb, "Special Measurements Physics/Instrumentation Package for JARLSBERG/FIRESTORM, U10ca, Ue10aa, Revision A, Final", EG\&G, Energy Measurements, Las Vegas Operations, SM:83E-108-20,12 October, 1983.

(3) Alfred E. Burer, "Containment Report for U10ca", Holmes \& Narver, Inc., NTS:A2:83-33, August 26, 1983.

(4) William G. Webb, "Special Measurements Final Engineering Report, JARLSBERG, U10ca, Ue10aa", EG\&G, Energy Measurements, Las Vegas Operations, SM:83E-108-19, 12 October, 1983. 
Distribution:

LLNL

TID (11)

Containment Vault

Burkhard, N.

Cooper, W.

Denny, $M$.

Dong, $R$.

Goldwire, $H$.

Heinle, R. (5)

Mara, $G$.

Moran, M.T.

Moss, W.

Olsen, C.

Patton, $\mathrm{H}$,

Pawloski, G.

Rambo, J.

Roland, $\mathrm{K}$.

Roth, B.

Valk, $T$.

Younker, L.

LANL

App, $F$.

Brunish, W.

Kunkle, $T$.

Trent, B.

\section{Sandia}

Chabai, A.

Smith, Carl W.
L-053

L- 045

L-221

L-221

L-049

L-205

L-140

L-221

L-221

L-049

$L-777$

L-200

L-221

L-205

L-221

L-200

L-221

L-049

L-154

L-203

F-659

F-659

F-665

F-664

MS-1159

MS-1159

\section{EG\&GIAVO}

Brown, $T$.

Gilmore, L.

Hatch, $M$.

Still, G.

Stubbs, $T$.

A-5

A-1

A-5

A-5

A-5

\section{EG\&G/NVO}

Bellow, B.

N 13-20

Davies, L.

Moeller, A.

Webb, W.

N 13-20

\section{DNA}

Ristvet, B.

S-Cubed

$$
\text { Peterson, E. }
$$

\section{Eastman Cherrington Environment}

1640 Old Pecos Trail, Suite H

Santa Fe, NM 87504

Keller, C. 